\title{
Relative sea-level changes and glacio-isostatic adjustment on the Magdalen Islands archipelago (Atlantic Canada) from MIS 5 to the late Holocene
}

Rémillard, Audrey M.; St-Onge, Guillaume; Bernatchez, Pascal; Hétu, Bernard; Buylaert, Jan-Pieter; Murray, Andrew S.; Lajeunesse, Patrick

\author{
Published in: \\ Quaternary Science Reviews
}

Link to article, DOI:

10.1016/j.quascirev.2017.07.015

Publication date:

2017

Document Version

Peer reviewed version

Link back to DTU Orbit

Citation (APA):

Rémillard, A. M., St-Onge, G., Bernatchez, P., Hétu, B., Buylaert, J-P., Murray, A. S., \& Lajeunesse, P. (2017). Relative sea-level changes and glacio-isostatic adjustment on the Magdalen Islands archipelago (Atlantic Canada) from MIS 5 to the late Holocene. Quaternary Science Reviews, 171, 216-233.

https://doi.org/10.1016/j.quascirev.2017.07.015

\section{General rights}

Copyright and moral rights for the publications made accessible in the public portal are retained by the authors and/or other copyright owners and it is a condition of accessing publications that users recognise and abide by the legal requirements associated with these rights.

- Users may download and print one copy of any publication from the public portal for the purpose of private study or research.

- You may not further distribute the material or use it for any profit-making activity or commercial gain

- You may freely distribute the URL identifying the publication in the public portal 


\section{Relative sea-level changes and glacio-isostatic adjustment on the Magdalen Islands archipelago (Atlantic Canada) from MIS 5 to the late Holocene}

Audrey M. Rémillard, Guillaume St-Onge, Pascal Bernatchez, Bernard Hétu, Jan-Pieter Buylaert, Andrew S. Murray \& Patrick Lajeunesse

Editor - Claude Hillaire-Marcel (Quaternary Science Reviews)

The Magdalen Islands (Québec, Canada) in the centre of the Gulf of St. Lawrence are located in a strategic position for providing an overview of the relative sea-level (RSL) history of the Maritime Provinces of eastern Canada. Although data are available for the coastal terrestrial areas of the Maritimes, data from the Gulf are very scarce and both the RSL and glacio-isostatic adjustment (GIA) models extrapolate for this central region. This study provides new stratigraphic and chronological data from four outcrops and two coring sites on the Magdalen Islands. In addition to the five samples used mainly for age control purposes, nine new luminescence ages are presented. With these new data added to the available literature, a new RSL curve is reconstructed for the LGM to the late Holocene period and a partial curve is proposed for the interval between the late MIS 4 to the MIS 3. Data also indicate a few insights for the MIS 5 period. Results reveal that for the LGM to the late Holocene, the curve corresponds to the J-shaped curve scenario recognized in the literature. The RSL changes during this period are the result of glacioisostatic rebound, migration and collapse of the peripheral forebulge, and eustatic sealevel changes. For the LGM to the early Holocene, glacio-isostatic depression curves displaying a few local differences are also proposed. For the late Holocene, the data constrain the curve between two types of indicators, i.e. marine and terrestrial, and indicate that the RSL has risen at least $3 \mathrm{~m}$ during the last two millennia. Sediments dated to the MIS 5 and the interval between the late MIS 4 and the MIS 3 illustrate that the GIA following the LGM also occurred for the MIS 5 interglacial and the MIS 3 interstadial. Finally, recent GIA models are discussed in light of the results of this paper.

Keywords: Glaciation; Sea level changes; Glacio-isostatic adjustment; Atlantic Canada; Luminescence dating; Sedimentology; MIS 5; MIS 3; Last Glacial Maximum; Holocene.

Audrey M. Rémillard (audrey.mercierremillard@uqar.ca) and Guillaume St-Onge, Institut des sciences de la mer de Rimouski (ISMER) \& GEOTOP, Université du Québec à Rimouski, 310 allée des Ursulines, Rimouski (Québec), G5L 3A1, Canada;

Pascal Bernatchez and Bernard Hétu, Département de Biologie, chimie et géographie \& Centre for Northern Studies (CEN), Université du Québec à Rimouski, 300 allée des Ursulines, Rimouski (Québec), G5L 3A1, Canada;

Jan-Pieter Buylaert, Nordic Laboratory for Luminescence Dating, Department of Geoscience, Aarhus University, and Technical University of Denmark, Centre for Nuclear Technologies, Risø Campus, DK-4000 Roskilde, Denmark;

Andrew S. Murray, Nordic Laboratory for Luminescence Dating, Department of Geoscience, Aarhus University, Risø Campus, DK-4000 Roskilde, Denmark;

Patrick Lajeunesse, Département de géographie \& Centre for Northern Studies (CEN), Université Laval, 2405 rue de la Terrasse, Québec (Québec), G1V 0A6, Canada. 


\section{Introduction}

Global sea-level rise is currently at the forefront of climate change research as it poses one of the most significant challenges facing coastal communities in the $21^{\text {st }}$ century (e.g. Church et al. 2013; Jevrejeva et al. 2014). Sea level is undeniably far from stable. During the Quaternary, for instance, global sea-level experienced substantial fluctuations, from a lowstand around -130 m (MIS 2; e.g. Yokoyama et al. 2000) to a highstand of more than +20 m (MIS 11; Candy et al. 2014). Sea-level fluctuates geographically and with time at varying rates, primarily as a consequence of the growth and decay of ice sheets and the subsequent dynamic response of the Earth to the related changes of surface loading (e.g. Lambeck et al. 2014). Our understanding of past changes is crucial since the pattern of present and future sea-level variations are likely to be analogous to past events (e.g. Gehrels 2010; Lambeck et al. 2010). In addition to the factors directly related to the climate such as thermal expansion or freshwater flux from the melting land-based ice sheets, geophysical forcings, especially glacial isostatic adjustment (GIA), also produce significant relative sea-level (RSL) variations at more local and regional scales (e.g. Cazenave \& Le Cozannet 2014). Although the Last Glacial Maximum (LGM) ended more than 20,000 yrs ago, GIA is still ongoing today in and near the areas that were affected by ice sheets (e.g. Tamisiea \& Mitrovica 2011). Today, GIA models are required to predict future changes in RSL and to develop accurate projections; these models must be as appropriate as possible and require therefore an adequate coverage of past RSL data (e.g. Lambeck et al. 2014; Goslin et al. 2015; Reynolds \& Simms 2015). 
Generally, the dynamics of RSL in formerly glaciated areas can be illustrated by three major theoretical postglacial RSL curves (e.g. Quinlan \& Beaumont 1981; Dyke \& Peltier 2000). Regions that were heavily ice-loaded during the LGM are influenced by a continuous emergence since deglaciation while the more distal regions are exposed to a continuous submergence (Fig. 1). The areas in between, located inside and just outside the ice margin, exhibit an initial high RSL followed by an emergence due to glacioisostatic rebound and the migrating forebulge, and finally, a submergence that is still ongoing today. This scenario is represented by a J-shaped RSL curve including a lowstand below current level (Fig. 1).

During the LGM, the Maritime Provinces of eastern Canada (including Québec) were covered by regional ice-caps that extended to the continental shelf; these ice-caps coalesced with each other and with the Laurentide Ice Sheet (LIS) which formed an ice stream in the Laurentian Channel (e.g. Stea et al. 1998, 2011; Shaw et al. 2006). The region was therefore at the limit of the LGM ice extent and so is expected to display all the RSL scenarios described above. Based on a considerable amount of data presented in the literature, Shaw et al. (2002) proposed the first complete RSL reconstruction for Atlantic Canada and the northeastern United-States since $15.8 \mathrm{ka}$ cal. BP. According to this model and the regional literature, the RSL on the Grand Banks of Newfoundland and the Sable Island area (offshore of Nova Scotia), where the peripheral forebulge was located, has been rising continuously since deglaciation, from approximately $-100 \mathrm{~m}$ up to the modern level (e.g. Scott et al. 1984, 1989). Conversely, the northern part of the Gulf of St. Lawrence was heavily ice-loaded by the LIS and the RSL has decreased since 
deglaciation, from approximately +130 m to the present-day level (e.g. Bigras \& Dubois 1987; Bell et al. 2005). Between these scenarios, the J-shaped RSL curve is well represented in the Maritimes and exhibits variability from site to site with respect to the former ice margins and the different timing of the passage of the migrating forebulge (e.g. Shaw et al. 2002; Bell et al. 2005). Although the coverage of RSL data is quite extensive for the coastal terrestrial areas, data from the Gulf of St. Lawrence are scarce. The Magdalen Islands (Fig. 2), located in the centre of the Gulf of St. Lawrence halfway between Prince Edward Island and Newfoundland, offer a strategic terrestrial record to complete the RSL history of the Gulf and therefore the Maritimes area. With the aim of reconstructing the glacial history of the archipelago and based mostly on subtidal deposits dated by optically stimulated luminescence (OSL), Rémillard et al. (2016) proposed a preliminary RSL curve from the LGM to the early Holocene period that shows a J-shaped curve. However, the data have not been discussed in detail in terms of RSL variations and GIA. Furthermore, RSL archives from MIS 3 (e.g. Rémillard et al. 2013) and MIS 5 (Dredge et al. 1992) have been observed on the Magdalen Islands. A more detailed analysis of these deposits would provide novel information and help reconstruct the RSL on a multi-temporal scale; this has never been previously proposed for the Maritimes provinces of eastern Canada where ages older than 16 ka are rather scarce. Such older RSL records are indeed rare in the literature at both the regional and global scales; the Magdalen Islands might therefore contribute to supplement the worldwide knowledge and the modelling effort on RSL as well as on Earth rheology. 
In this paper, we aim to: i) describe new sites from the Magdalen Islands and present sedimentological and chronological data used to produce new RSL records for the MIS 5, the interval between the MIS 4/MIS 3, and the late Holocene; ii) add MIS 2 data points to the RSL record of the Magdalen Islands presented by Rémillard et al. (2016); iii) reconstruct the RSL history of the Magdalen Islands from the available literature and the data presented in this study; and iv) analyse the patterns of glacio-isostatic crustal adjustment.

\section{Background}

\subsection{Geological and geomorphological settings}

The Magdalen Islands lie in the shallow waters $(<100 \mathrm{~m})$ of the Magdalen Shelf near the centre of the Gulf of St. Lawrence $\left(47^{\circ} \mathrm{N}\right)$ (Fig. 2). The islands are built on Carboniferous to Permian sedimentary substrata outcropped by volcanic basaltic strata, typically in fault-bound blocks (Brisebois 1981; Giles 2008). As a result, the geomorphology of the islands is dominated by basaltic conical hills surrounded by sandstone and shale platforms slightly inclined towards the sea and interpreted as cryopediment surfaces (Paquet 1989; Rémillard et al. 2016). The sandstone is mainly composed of quartz contained in a calcareous and ferruginous cement; it is generally porous and friable, and so deeply weathered, to 1 to $2 \mathrm{~m}$ beneath ground surface (Brisebois 1981).

On the southern islands (Havre-Aubert, Entry, Cap-aux-Meules Islands, and Havre-aux-Maisons Islands), the bedrock is overlain discontinuously by 0.5 up to $10 \mathrm{~m}$ thick Quaternary sediments (e.g. Dredge et al. 1992; Rémillard et al. 2013). In the 
northern part of the archipelago (the Pointe-aux-Loups and Grande-Entrée Islands), sedimentary bodies can be 20 m thick (e.g. Dredge et al. 1992; Vigneault 2012). Six of the seven islands are connected to each other by Holocene barrier beaches (tombolos) (Rémillard et al. 2015a). The cliffs of the Magdalen Islands have the highest rocky coastal-cliff erosion rates in the Estuary and Gulf of St. Lawrence (Bernatchez \& Dubois 2004); the mean retreat rate throughout the archipelago is $~ 0.3 \mathrm{~m} /$ year (1963 to 2008), but reaches up to $\sim 1.5 \mathrm{~m} /$ year at some sites (Bernatchez et al. 2012). However, the overall sediment budget of the Magdalen Islands is almost in equilibrium; cliff-eroded sediments are transported by longshore drift, mixed with littoral sediment, and accumulate in littoral drift convergence zones (Drapeau \& Mercier 1990). Rémillard et al. (2015a) suggest that this very dynamic sediment transfer has been active for at least the last two thousand years.

\subsection{Glacial and relative sea-level (RSL) history}

The glacial history of the Maritime Provinces of eastern Canada is described as a series of recurrent interactions between the sea and the land-based ice-caps of different origins, resulting in a complex RSL history in the Gulf of St. Lawrence that is variable both regionally and locally (e.g. Stea et al. 1998, 2011; Josenhans \& Lehman 1999; Shaw et al. 2002, 2006; Stea 2004; Bell et al. 2005; Josenhans 2007). However, the glacial history and subsequent RSL changes of the Magdalen Islands have been debated for over a century and remained unclear until the recent work of Vigneault (2012) and Rémillard et al. (2013, 2016). The major issue was whether the islands were glaciated during the LGM. The different hypotheses raised by several researchers have complicated RSL reconstructions for this specific area of the Gulf of St. Lawrence, mainly because of the 
lack of a robust chronological framework. Although the Appalachian Glacier Complex (ACG) model (e.g. Stea et al. 1998, 2011; Stea 2004; Shaw et al. 2006), which suggests that the Magdalen Islands were glaciated during the LGM, is generally accepted in the regional literature, no data are derived from the archipelago and so the model extrapolates to include the islands and surroundings. Recently, Rémillard et al. (2013, 2016) presented extensive sedimentological and chronological data offering a detailed glacial history for the Magdalen Islands. Based on sedimentological and chronological evidence, these authors suggested that the islands were at the junction of two different ice-caps during the LGM. The southern islands were glaciated by the Escuminac ice-cap located in the western Gulf of St. Lawrence (Stea et al. 2011), while the northern archipelago was glaciated at the end of the LGM ( 20 ka) by an ice flow from Newfoundland. The evidence that the Newfoundland ice-cap has reached the northern archipelago is threefold. First, glaciotectonic deformations showing a thrust orientation towards the WSW were observed in either the bedrock or the marine sediment that underlie the Newfoundland till. Secondly, clast fabrics measured in the till at different sites revealed that the mean vectors are mostly oriented ENE-WSW. Finally, from site to site, the till presents similar petrographic assemblages typical of Appalachian lithology (e.g. metaquartzite, gabbro, anorthosite, granitoids, jasper, chert, etc.). The clast fabric and glaciotectonic deformation orientations added to the Appalachian lithology point to a glaciation from the Newfoundland ice-cap.

Rémillard et al. (2016) also suggested an early deglaciation, a high RSL and periglacial conditions for the southern islands as early as 23 ka, while the northern 
islands were still ice-covered. The preliminary post-LGM RSL curve proposed by Rémillard et al. (2016) suggests that around 15 ka, the entire archipelago was deglaciated

and partially submerged until $\sim 11 \mathrm{ka}$. The RSL passed below the modern RSL around $10.7 \mathrm{ka}$ cal. BP and dropped at least to a depth of $17 \mathrm{~m}$ around $9.8 \mathrm{ka}$ cal. BP. All these data are quite consistent with the J-shaped curve scenario. In addition to these data, it should be noted that Rémillard et al. (2013, 2016) and Dredge et al. (1992) observed coastal and lagoonal deposits on the southern archipelago dated to the MIS 3 (+15 m) and to the MIS 5 (modern level), respectively.

\section{Methodology}

\subsection{Sites}

Four new stratigraphic sequences, all located in coastal cliffs, are described in detail (Fig. 2). Three are located on Entry Island (Cap-Blanc, Drift, and Beach) and one on Cap-auxMeules Island (Camping). Four sites are discussed for chronological control purposes only; at the Plaisance site, located on the tombolo connecting Cap-aux-Meules and Havre-Aubert Islands, and the Airport site, located on Havre-aux-Maisons Island, current coastal sediments were sampled as modern analogues. At the ACE and Bassin sites, both located on Havre-Aubert Island, samples were collected for comparison with independent age control, with radiocarbon and U/Th disequilibrium ages, respectively. Note that the Plaisance, Airport, and ACE sites were also used for chronological control in Rémillard et al. (2016) and one sample of the Plaisance site (OSL87) was also discussed in Rémillard et al. (2015a). In addition to the stratigraphic sequences, a vibracore (WINK) 
was used to obtain samples at different depths at 2 sites: Bassin-aux-Huîtres (BAH) (Grande-Entrée Island) and Hospital Pond (Cap-aux-Meules Island) (Fig. 2).

\subsection{Sedimentological analyses}

Grain-size distribution of matrices from both stratigraphic sequences and cores was determined with a Beckman-Coulter particle size analyzer LS 13320 (0.04 - $2000 \mu \mathrm{m})$ on 24 disaggregated samples and processed with Gradistat software using the logarithmic method of Folk \& Ward (1957) (Blott \& Pye 2001; Table 1). Altitudes of deposits in the stratigraphic sequences were measured in situ using a Trimble RTK D-GPS $( \pm 0.015 \mathrm{~m}$ vertical uncertainty).

\subsection{Radiocarbon dating}

Two samples of shell fragments collected from the vibracores were prepared for radiocarbon dating at the radiochronology laboratory of Université Laval and analyzed at the Keck Carbon Cycle AMS Facility at the University of California in Irvine (Table 2). The conventional ${ }^{14} \mathrm{C}$ ages were calibrated using the CALIB 7.1 program with the INTCAL13 or MARINE13 calibration dataset (Reimer et al. 2013). All radiocarbon ages discussed in this paper are listed in Table 2.

\subsection{Quartz OSL and feldspar (post-IR) IRSL dating}

\subsubsection{Sampling, sample preparation and instrumentation}

Sediments collected for luminescence dating were sampled by hammering opaque plastic cylinders $5 \mathrm{~cm}$ diameter and $30 \mathrm{~cm}$ long into the deposits. All samples were prepared under subdued orange light. The outer $\sim 5 \mathrm{~cm}$ ends of the samples were used for water 
content determination and dose rate analysis. Samples were wet-sieved and the 180-250 $\mu \mathrm{m}$ fraction was etched with $10 \% \mathrm{HCl}, 10 \% \mathrm{H}_{2} \mathrm{O}_{2}$ and $10 \% \mathrm{HF}$ in the usual manner. Heavy liquid separation $(2.58 \mathrm{~g} / \mathrm{ml})$ was then used to separate quartz from K-rich feldspar grains. Finally, the quartz-rich extract was etched using concentrated HF (40\%) for $1 \mathrm{~h}$ to remove any remaining feldspar and the outer alpha-irradiated layer from the quartz grains.

All measurements employed Risø TL/OSL readers (model DA-20) each equipped with blue LEDs (470 nm, 80 $\mathrm{mW} \mathrm{cm}^{-2}$ ), infrared (IR) LEDs $\left(870 \mathrm{~nm}, \sim 135 \mathrm{~mW} \mathrm{~cm}^{-2}\right.$ ) and with an accurately calibrated ${ }^{90} \mathrm{Sr} /{ }^{90} \mathrm{Y}$ beta source (Bøtter-Jensen et al. 2010). Quartz OSL was detected through $7.5 \mathrm{~mm}$ of Schott U-340 (UV) filter and feldspar IRSL through a combination of Corning 7-59 and Schott BG-39 filter (blue-violet). The quartz and K-feldspar extracts were mounted on $\sim 8 \mathrm{~mm}$ diameter stainless steel discs and cups, respectively, using "Silkospray" silicone oil as fixing agent. The single-aliquot regenerative-dose (SAR) protocol (Murray \& Wintle 2000; 2003) was used for all equivalent dose $\left(D_{e}\right)$ determinations. Prior to OSL measurement, the purity of the quartz extracts was confirmed by an OSL IR depletion test (Duller 2003); all samples had OSL IR depletion ratios within $10 \%$ of unity, indicating that there was no significant contribution from feldspar or other IR-sensitive components to the blue-stimulated OSL signals. Quartz aliquots were stimulated at $125{ }^{\circ} \mathrm{C}$ using blue light (90\% power) for $40 \mathrm{~s}$; preheat conditions are discussed in Section 3.4.4. Quartz $\mathrm{D}_{\mathrm{e}}$ values were calculated using the first $0.32 \mathrm{~s}$ of the signal and a background based on the following $0.32-0.64 \mathrm{~s}$ to 
minimize any possible contribution of non-fast components (Cunningham \& Wallinga 2010).

Feldspar measurements were carried out on two samples only, OSL51 and OSL101. The feldspar aliquots were first stimulated at $50{ }^{\circ} \mathrm{C}\left(\mathrm{IR}_{50}\right)$ and then at $290{ }^{\circ} \mathrm{C}$ (pIRIR290) each using IR light for $100 \mathrm{~s}$. Before measurement of natural, regeneration and test dose signals, the aliquots were pre-heated at $320^{\circ} \mathrm{C}$ for $60 \mathrm{~s}$. At the end of each SAR cycle a high temperature IR clean-out $\left(100 \mathrm{~s}\right.$ at $\left.325^{\circ} \mathrm{C}\right)$ was inserted (e.g. Thiel et al. 2011). The choice of the measurements protocol is discussed in Section 3.4.4. Feldspar $\mathrm{D}_{\mathrm{e}}$ values were calculated using the first $10 \mathrm{~s}$ of the signal and a background based on the final $20 \mathrm{~s}$.

\subsubsection{Radionuclide analysis and dosimetry}

Approximately $250-300 \mathrm{~g}$ of material was dried, ground and ignited $\left(24 \mathrm{~h}\right.$ at $\left.450^{\circ} \mathrm{C}\right)$ and subsequently cast in wax in a fixed cup-shaped geometry. After three weeks of storage to let ${ }^{222} \mathrm{Rn}$ reach equilibrium with its parent ${ }^{226} \mathrm{Ra}$, the cups were counted on a highresolution gamma spectrometer for at least $24 \mathrm{~h}$ following Murray et al. (1987).

Field water contents were measured when the samples were first opened in the laboratory. As discussed in Rémillard et al. (2016), many of these samples were deposited under water but, compared to their subsequent burial time, were uplifted shortly after deposition. Other samples were deposited sub-aerially. We have assumed life time water content of 0.5 of saturation $( \pm 6 \%)$. The formulas in Aitken (1985) were used to correct the calculated dry dose rates, derived from radionuclide concentrations, to 
give the life-time averaged dose rates. Finally a cosmic ray dose rate was estimated from the assumed lifetime burial depth (Prescott \& Hutton 1994).

Table 3 summarises the resulting total dose rates to $180-250 \mu \mathrm{m}$ quartz grains. The corresponding dose rate to feldspar grains is greater by $0.81 \pm 0.05 \mathrm{~Gy} / \mathrm{ka}$ because of internal potassium (and rubidium) and by $0.04 \pm 0.03$ because of the assumed larger internal radioactivity of feldspars grains compared to quartz grains.

\subsubsection{Age control}

Rémillard et al. (2016) have measured the doses recorded by modern analogue samples from beach and subtidal environments and have shown that the apparent ages are negligible compared to those discussed later in this paper. They also argued using differential bleaching of feldspar and quartz that all their quartz samples appear to have been well-bleached at deposition. Finally, they found good agreement between OSL ages and independent radiocarbon age estimates. In our present study we add to this age control with one sample collected in a silty-sand unit interpreted as a lagoonal deposit (OSL101) from the Bassin site (Figs. 2, 3); this sample has an independent age estimate derived from U/Th acquired from overlying woody peat (Dredge et al. 1992).

\subsubsection{Luminescence characteristics and reliability of the ages}

Quartz

Fig. 4A illustrates a typical sensitivity-corrected growth curve with a natural OSL stimulation decay curve (inset), together with a decay curve from a quartz calibration standard (Hansen et al. 2015). The reproducibility of laboratory measurements using this 
material is illustrated by the two measurements of the sensitivity corrected signal at 24.8 Gy. The average of this recycling ratio for all available quartz measurements is $1.10 \pm 0.03$ ( $\mathrm{n}=192)$. The growth curve also passes very close to the origin; the average recuperation is $-0.01 \pm 0.04 \%$ of natural $(\mathrm{n}=192)$. The $\mathrm{D}_{0}$ for this aliquot (Fig. $\left.4 \mathrm{~A}\right)$ is $110 \pm 30$ Gy suggesting that we may be able to use this material for $D_{e}$ estimates up to 220 Gy (Wintle \& Murray 2006).

The dependency of the $\mathrm{D}_{\mathrm{e}}$ and the dose recovery ratio on thermal pre-treatment for samples OSL53 and OSL55 was tested by varying the pre-heat temperature; the thermal pre-treatment employed after giving the test dose (the 'cut-heat') was $40{ }^{\circ} \mathrm{C}$ below the preheat temperature (except for 160 and $180^{\circ} \mathrm{C}$ preheat for which the cut heat was kept fixed at $160^{\circ} \mathrm{C}$ ) (Fig. 4B). Dose recovery tests began with a blue-light exposure for two periods of $40 \mathrm{~s}$ at room temperature, separated by a pause of $10 \mathrm{ks}$, before administering the given dose. This given dose was then measured in the usual manner. Both $D_{e}$ estimates and dose recovery ratios have a pronounced dependence on preheat temperature with the dose recovery ratio only consistent with unity for preheats $\leq 220{ }^{\circ} \mathrm{C}$ (Fig. 4C). The $\mathrm{D}_{\mathrm{e}}$ values are also relatively insensitive to preheat temperatures $<220^{\circ} \mathrm{C}$. Because of this, we chose a preheat/cut-heat combination of $200 / 160{ }^{\circ} \mathrm{C}$. Further dose recovery measurements were made using 6 aliquots of all samples and given doses varying between 25 Gy and 65 Gy depending on the approximate $D_{e}$ of each sample (inset Fig. 4C); the average dose recovery ratio is $0.981 \pm 0.020(\mathrm{n}=42)$, confirming that the chosen SAR protocol is suitable for these samples. 


\section{Feldspars}

Fig. 5A presents a representative pIRIR 290 stimulation curve and the resulting dose response curve for sample OSL51. The $\mathrm{D}_{0}$ for this aliquot (Fig. 5A) is $530 \pm 40 \mathrm{~Gy}$ suggesting that we can use this material for $\mathrm{D}_{\mathrm{e}}$ estimates at least up to 1000 Gy. A dose recovery experiment was carried out by adding known laboratory doses (100 and 596 Gy) each to 6 aliquots of the modern sample OSL78 with measured residual doses of $10.6 \pm 0.7$ Gy $(n=6)$ and $43.7 \pm 1.5$ Gy $(n=6)$ for the $I_{50}$ and pIRIR 290 signals, respectively. Fig. 5B summarises the doses measured on these laboratory irradiated aliquots, after subtraction of the average measured residual doses. The average dose recovery for the $\mathrm{IR}_{50}$ signal is $0.690 \pm 0.008$ and for the pIRIR 290 signal is $1.02 \pm 0.03$ (slope of the straight lines passing through the origins in Fig. 5B).

\subsubsection{Reliability of the luminescence ages}

The luminescence characteristics of the samples presented in this study are very similar to the samples presented in Rémillard et al. (2015a, 2015b, 2016); the OSL signals are

dominated by fast component, have satisfactory luminescence characteristics, and the dose recovery ratios are consistent with unity (Fig. 4). As discussed above, Rémillard et al. (2015a, 2016) used modern analogues to argue that these samples were probably wellbleached at deposition and independent radiocarbon age control to demonstrate the accuracy of quartz ages of $\sim 40-45$ ka. Note that the total uncertainty on the luminescence ages in Tables 4 and 5 ranges between 7 and 9\%; uncertainties on the luminescence ages are typically of the order of 5-10 \% (Murray \& Olley, 2002). 
The OSL age of the sample taken at the Bassin site can be compared with a U/Th independent age control (Fig. 3). The measured quartz age is 79 \pm 9 ka (OSL101; Table 4) while the U/Th ages presented by Dredge et al. (1992) for the same unit are

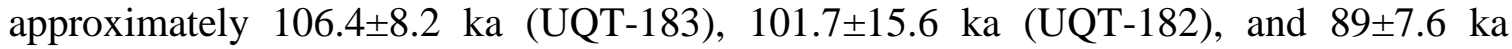
(UQT-184). In contrast to the observation of Rémillard et al. (2016) using 40-45 ka samples, here the quartz age seems to underestimate the U/Th ages. However, the pIRIR $_{290}$ age obtained from the same sample gives an age of $112 \pm 8$ ka (Table 5), in better agreement with the U/Th. This quartz underestimate is not surprising; the $D_{e}$ values from OSL101 are 160 Gy. Several papers have suggested that quartz begins to underestimate for doses >150 Gy (e.g. Chapot et al. 2012). We conclude that the pIRIR290 protocol is probably more accurate for our two samples with the largest doses, OSL51 and OSL101 with quartz De values of 156 \pm 7 Gy and $164 \pm 11$ Gy.

\section{Results}

\subsection{Stratigraphic sequences}

\subsubsection{Cap Blanc}

The Cap Blanc site is located on the southeast side of the Entry Island (Fig. 2). Sediments are $\sim 10 \mathrm{~m}$ thick and fill a $\sim 10 \mathrm{~m}$ wide bedrock depression with an elevation of between 30 and $40 \mathrm{~m}$ a.s.l. (Fig. 6A). Five units were identified in this sequence. The first unit (U1) lies directly on the weathered bedrock and is composed of $\sim 2 \mathrm{~m}$ of white and red well-rounded and well-sorted fine to medium sand (Fig. 6B; Table 1). U1 is slightly horizontally stratified; whitish fine sand is dominant, but alternates with beds of very fine 
to silty reddish sand. Luminescence measurements using quartz gave an age of $55 \pm 5 \mathrm{ka}$ (OSL53; Table 4). U1 grades up gradually through U2 which is composed of $\sim 1 \mathrm{~m}$ thick massive red fine to very fine sand (Fig. 6C; Table 1). A few beds of red silt are observed within the unit. An age of $60 \pm 4$ ka was acquired from the top of U2 (OSL54; Table 4). U2 is sharply truncated by a $1 \mathrm{~m}$ thick clast-supported and very poorly-sorted compact diamict (U3) comprising exclusively angular pebbles of unstriated local basalts (Figs. 6C, $\mathrm{D}$; Table 1). U3 is overlaid by $\mathrm{U} 4$ which is composed of $\sim 2.5 \mathrm{~m}$ thick horizontally stratified well-rounded and well-sorted medium to fine white sand (Figs. 6D, E; Table 1). The base of U4 was dated to $51 \pm 4$ ka (OSL55) and the top to $61 \pm 4$ ka (OSL56; Table 4). U4 is truncated by a 2 to $3 \mathrm{~m}$ thick clast-supported and very poorly-sorted compact diamict (U5) (Fig. 6E, Table 1). As with U3, U5 is exclusively composed of angular and unstriated basalt pebbles. U5 also comprises variably sized lenses of brown sand. A sample for OSL dating was collected from a sandy lens and the resulting age is $60 \pm 5 \mathrm{ka}$ (OSL57; Table 4).

\section{Interpretations}

Owing to the gradual evolution of slightly stratified mostly medium whitish sand to more homogeneous fine to very fine red sand, U1 and U2 are interpreted as a transgressive period of high RSL. U1 corresponds to a subtidal unit that evolves gradually into shallow water marine deposit (U2). The massive diamict that truncates U2 is associated with a periglacial colluvial deposit very similar to those observed on the Cap-aux-Meules Island by Paquet (1989) and Rémillard et al. (2016). U3 sharply truncates a shallow water marine deposit, suggesting that the colluvial deposits produced by the central hills definitely reached the sea. At some point, the colluvial activity ceased and RSL was still 
high allowing the deposition of U4 (interpreted as a littoral deposit). Indeed, the wellsorted nature of the medium to fine white sand, its parallel and horizontal bedding, and the presence of small-scale ripples strongly suggest an intertidal deposit (beach). U4 probably corresponds to the regressive period following the transgressive phase suggested by U1 and U2 whose deposition was interrupted by the colluvial periglacial activity. U4 is also truncated by a massive diamict very similar to U3 and also associated with periglacial colluviation. The ages obtained from the entire sequence range between $61 \pm 4$ ka (OSL56) and 51 \pm 4 ka (OSL55). All these ages are indistinguishable from the average of $57 \pm 4 \mathrm{ka}(\mathrm{n}=5)$ and indicate that this entire sequence associated with a high RSL (at least $\sim+35 \mathrm{~m}$ ) and periglacial conditions have occurred either during the late MIS 4 or early MIS 3.

\subsubsection{Drift}

The Drift site is located $\sim 300 \mathrm{~m}$ to the east of the Cap Blanc site (Fig. 2). This site exposes a single unit that lies directly on the weathered bedrock at an elevation of $\sim 39 \mathrm{~m}$. The deposit is composed of poorly-sorted fine to very fine silty red sand (Fig. 7A, Table 1). The unit is quite homogeneous, moderately compact and massive; only few thin lenses of whitish sand are observed. The unit also displays varying sized of scattered subangular to sub-rounded contoured pebbles. One basalt boulder of more than a meter in diameter is exposed in the unit; a layer of red sand between the bedrock and the boulder indicates that it is not part of the substratum (Fig. 7A). OSL measurements gave an age of 24.6 \pm 2.0 ka (OSL58; Table 4). 
Interpretations

Owing to homogeneous and massive facies composed of fine to very fine silty sand, a moderately compacted nature, and the occurrence of scattered pebbles of contoured subrounded shape, the Drift site is interpreted as a glaciomarine deposit. The scattered pebbles and the boulder are interpreted as dropstones. The unit is very similar to the glaciomarine part of the Drift des Demoiselles on the Havre-Aubert Island described by Rémillard et al. (2013). The age of $24.6 \pm 2.0 \mathrm{ka}$ from this unit suggests a deposition immediately after the MIS 2 deglaciation of the southeastern Magdalen Islands, consistent with the relative MIS 2 age associated to the Drift des Demoiselles on the Havre-Aubert Island (Rémillard et al., 2013).

\subsubsection{Beach}

The Beach site is an active coastal cliff located on the upper beach of the southwest coast of Entry Island (Fig. 2). The sequence exposes $\sim 6.5 \mathrm{~m}$ of moderately to poorly-sorted fine to very fine red sand with (Fig. 7B, Table 1). The unit is slightly sub-horizontally stratified; red sand is dominant, but alternates with beds of white sand. The unit also exposes cross-bedding structures, micro-scale ripples, thin lenses of white sand, and scattered small clasts (gravel). An age of 15.8 \pm 1.1 ka (OSL59; Table 4) was obtained from the basal part of the unit.

\section{Interpretations}

All the characteristics of the Beach site correspond to sediments deposited in shallow marine conditions (infratidal to subtidal). The facies and the sedimentological data are very similar to many other subtidal and shallow water marine deposits elsewhere on the Magdalen Islands (cf. Rémillard et al. 2016). The elevation and the age of the deposit 
suggest a higher RSL of at least $+10 \mathrm{~m}$ at $\sim 16 \mathrm{ka}$, consistent with the indicators of a higher RSL listed by Rémillard et al. (2016) on the Havre-Aubert Island, also on the southern part of the archipelago, and all OSL dated to younger than $20 \mathrm{ka}$.

\subsubsection{Camping}

The Camping site is located on the southeast side of the Cap-aux-Meules Island (Fig. 2). An approximately 60 meters wide crested-shape deposit lies directly on the sandstone bedrock (Fig. 8A). The deposit is a maximum of $\sim 4 \mathrm{~m}$ thick at an elevation of $+14 \mathrm{~m}$. A single unit is exposed, composed of fine to medium red sand alternating with gravelly beds of 10 to $>30 \mathrm{~cm}$ thick, both moderately to poorly-sorted (Fig. 8B, Table 1). The sandy beds are slightly stratified with few undulating beds. The gravel (with few pebbles) is mostly composed of sub-angular local basalt. A pIRIR 290 age of $115 \pm 8$ ka (OSL51; Table 5) was obtained from the deposit; the material is too old to be dated reliably using quartz.

\section{Interpretations}

The deposit at the Camping site is interpreted as a littoral unit (barrier beach) whose depositional environment is characterised by a low energy (sandy beds) with periods of higher energy (gravel beds). The deposit is associated with a higher RSL of at least +14 m. At two standard deviations, the age of the deposit range between 100 and $130 \mathrm{ka}$, a wide period corresponding to MIS 5e - c.

\subsubsection{Coring sites}

Two cores were sampled at two different sites on the archipelago using vibrocoring equipment (WINK): Hospital Pond (9-m length) on the Cap-aux-Meules Island and 
Bassin-aux-Huîtres (BAH; 5-m length) on the Grande-Entrée Island (Fig. 2). Both cores are very homogeneous from the base to the top and expose massive sand. At the Hospital Pond site, the core is mostly composed of well-sorted fine to very fine grayish brown sand (PS17 to PS19) with layers of medium to coarse sand (PS15, PS16) (Table 1). At the BAH site, the core is mainly composed of well-sorted medium to coarse brownish sand (Table 1). Both cores contain scattered gravel and shell fragments. At a depth of $-5 \mathrm{~m}$, shell fragments gave an age of 636 \pm 75 cal. BP (UCIAMS-134726) for the Hospital Pond core and $418 \pm 84 \mathrm{cal}$. BP (UCIAMS-134725) for the BAH core.

\section{Interpretations}

The characteristics of both cores, i.e. the massive and uncompacted nature, the particle size, the presence of shell fragments, etc., correspond to sediments deposited in shallow water marine conditions (infratidal to subtidal). According to the two ages acquired, these sediment bodies were deposited while the RSL around the archipelago was rising (Rémillard et al. 2015a). Although the water depth at deposition is unknown, these dated samples give minimum level for RSL reconstructions.

\subsection{Relative sea-level (RSL) curves}

Sea-level index point methods are often used when reconstructing relative palaeo-RSL (e.g. Murray-Wallace \& Woodroffe 2014; Reynolds \& Simms 2015). These methods use a quantitative relationship between a dated indicator (e.g. sediment, landforms, biological assemblages, etc.) and its correlated past mean sea-level; this relationship is also called the indicative meaning. However, only few indicators form or deposit at mean RSL and most have a limiting relationship to a former level (limiting data), i.e. that the RSL must have been at or above (marine indicator), or at or below (terrestrial indicator) the dated 
point. The RSL curves for the Magdalen Islands (Fig. 9) have been drawn from the data listed in Table 2 (radiocarbon) and Table 6 (luminescence). These data were mainly compiled from marine indicators, i.e. glaciomarine, shallow marine or subtidal deposits. It is therefore impossible to assign an indicative meaning or limiting points to these data since they could have been deposited in varying water depths. These are not accurate indicators of RSL; they only testify that the RSL was higher than their current altitude. For the ACE site, in addition to the two luminescence ages (OSL03 and OSL04), three radiocarbon ages are also available (Table 2). For the late Holocene period, terrestrial indicators (tree trunks, peat) located on modern beaches inventoried by Juneau (2012) were also used to reconstruct the RSL curves; the age and elevation of these indicators suggest a lower RSL and are presented in Table 2. In addition to the two radiocarbon ages from the coring sites presented above (Table 2), two samples of a core also acquired by vibrocoring (Les Sillons site; cf. Rémillard et al. 2015a) dated by luminescence to $1.30 \pm 0.05 \mathrm{ka}$ and $1.14 \pm 0.04 \mathrm{ka}$ at 9 and $7.5 \mathrm{~m}$ depth, respectively, were added to the curve (Fig. 9A). Finally, a lowstand event is evidenced on the curve by the cross (Fig. 9). This event is identified by an organic horizon found by the Canadian Salt Company Seleine Mines at a depth of $17 \mathrm{~m}$ under modern sea-level observed when they drilled a well (cf. Rémillard et al. 2016). A radiocarbon age of $~ 9.8$ cal. ka BP was derived from a well-preserved piece of wood recovered from this horizon.

This series of past RSL evidence reveals that the post-LGM RSL curve for the Magdalen Islands is J-shaped as proposed by Rémillard et al. (2016) and theoretically 
presented by Quinlan \& Beaumont (1981) (Fig. 9A). The data also suggest a partial RSL curve for the interval between the end of the MIS 4 and the MIS 3 (Fig. 9B).

\section{Discussion}

\subsection{Last Glacial Maximum and subsequent RSL variations}

The new data presented in this paper allows a more detailed analysis of the age-elevation data and provide an improved understanding of the glacial history of the Magdalen Islands; this new information leads us to more specific interpretations. We start by reiterating the conclusion from Rémillard et al. (2016) that all the evidence suggests that these deposits were well-bleached at the time of deposition. Thus there is no reason to suspect age overestimation in our samples arising from poor-bleaching. With this in mind, the glaciomarine deposit located at an elevation of $+40 \mathrm{~m}$ on the Entry Island and dated to $25 \pm 2 \mathrm{ka}$ (OSL58) is the oldest record observed for the LGM period and suggests a very early deglaciation of the southeast part of the islands. A similar unit, named the Drift des Demoiselles and interpreted as a glacial diamict evolving into a glaciomarine deposit, has been observed at different sites on the Havre-Aubert Island by Rémillard et al. (2013). Based on a relative chronology, they associated the Drift des Demoiselles with the LGM glaciation and the following deglaciation, which is consistent with the age of 25 ka provided from a very similar deposit on the Entry Island. Even considering a lower limit of two standard deviations, i.e. $21 \mathrm{ka}$, the deglaciation occurred very early and involves open waters at least for a part of the Laurentian Channel (Cabot Strait) at that time, although most of the deglaciation models suggest an opening of the Laurentian Channel around 17 ka cal. BP (e.g. Shaw et al. 2006; Josenhans 2007; Stea et al. 2011). 
The single LGM age on the Entry Island is supported by the ages acquired from subtidal deposits on the Havre-Aubert Island (18 ka; OSL19), the Cap-aux-Meules Island (23 ka; OSL47), and the Havre-aux-Maisons Island (23 ka; OSL63) (Table 6). On the HavreAubert Island, the subtidal deposits overlie the Drift des Demoiselles. Based on the these ages and the deglaciation model of Josenhans \& Lehman (1999) and Josenhans (2007), Rémillard et al. (2016) suggested that while a "switched-off” ice stream was partly filling the Laurentian Channel around $20 \mathrm{ka}$, an ice-free section has allowed marine waters to invade the Gulf of St. Lawrence at least around the southern archipelago. The data presented here are consistent with this hypothesis and suggests an even earlier partial deglaciation, i.e. at $\sim 25 \pm 2 \mathrm{ka}$. The southern archipelago is assumed to have been glaciated in a southeastward movement by the Escuminac ice-cap whose centre of dispersion was located in the northwestern Gulf of St. Lawrence (Rémillard et al. 2013; 2016). The series of ages from $25 \mathrm{ka}$ on the Entry Island (glaciomarine deposit) to 23-18 ka on (subtidal deposits) on the southern islands indicate a deglaciation from east to west consistent with the Escuminac glaciation. Such a scenario is also consistent with retreat of the glacier to the west, as indicated by Josenhans (2007). While the southern islands were deglaciated, the northern archipelago was still glaciated by a lobe of the Newfoundland ice-cap evidenced by the Grande-Entrée till dated to 20 ka (Rémillard et al. 2016). The oldest age from the subtidal deposits that overlie the Grande-Entrée till is 15.1 \pm 1.1 ka (OSL23; Table 6). Although there are still discrepancies to address, this interpretation attempts to consider both our data and those published in previous studies. In order to refine our hypotheses, a better chronological framework of the period between 25 to 15 ka would be required. 
From the elevation, location, and the age of each point, it is possible to discuss on an approximate glacio-isostatic depression by comparing the RSL to global sea-level curves available for that period. Once more, since the water depth is unknown for all points, the depression values are considered as minimum but give an approximation of the GIA dynamic that occurred in the central Gulf of St. Lawrence. According to the eustatic curves proposed in the literature for the last glaciation/deglaciation, the global sea-level stood approximately 120-130 m under the modern level between 25 and 20 ka (e.g. Yokoyama et al. 2000; Lambeck \& Chappell 2001; Caputo 2007; Stanford et al. 2011). This suggests that when the glaciomarine unit was deposited on the Entry Island (currently at $+40 \mathrm{~m}$ ), the area was affected by a glacio-isostatic subsidence of more than 160-170 m (Fig. 10). On the same island, the shallow marine deposit (Entry - Beach site) dated to $15.8 \pm 1.1 \mathrm{ka}($ OSL59) at $+2.6 \mathrm{~m}$ indicates a depression of $>100 \mathrm{~m}$ since the global sea-level was 100 m under the modern level at 16 ka (Stanford et al. 2011). These two ages on the Entry Island suggest a glacio-isostatic rebound of $>60 \mathrm{~m}$ in approximately $9 \mathrm{kyr}$. The scenario on the Entry Island is quite consistent with the ages of 18-17 ka acquired on subtidal deposit at the AP-DEM site on the Havre-Aubert Island at an elevation of +14 m (Fig. 9A; Table 6). All these deposits suggest a glacio-isostatic subsidence of roughly 115 m between 18 and 16 ka for the southern islands (Fig. 10). On the western part of the Havre-Aubert Island, two sites exposing subtidal deposits dated to $11.6 \mathrm{ka}$ at $+24 \mathrm{~m}$ (ACW site; OSL06) and to $9.8 \mathrm{ka}$ at +14 m (AC site; OSL12) (Table 6), suggest a crustal depression of about $90 \mathrm{~m}$ to $55 \mathrm{~m}$ (Fig. 10), respectively, 
since the global sea-level passed from $\sim 65$ to $40 \mathrm{~m}$ below the modern level for the same period (Stanford et al. 2011).

For the Cap-aux-Meules and Havre-aux-Maisons Islands, the scenario is slightly different. All the dated subtidal deposits are exposed at lower elevation than the southern islands, i.e. $<10 \mathrm{~m}$ (Fig. 9A). Two deposits dated to $23 \mathrm{ka}$, at the HAM and Fatima sites, are displayed at $+9 \mathrm{~m}$ and $+5 \mathrm{~m}$, respectively, involving a glacio-isostatic depression of 130-140 m (Fig. 10). This subsidence value is a little less than what we observe for the Entry Island. The glacial history of these islands is also different. There is no strong evidence of a glaciation on the central islands. Based on Paquet (1989) and Dredge et al. (1992) as well as on their own observations, Rémillard et al. (2016) suggested that the central islands were located at the margins of both Escuminac and Newfoundland icecaps. The ice thickness might have been less important on these islands compared to the southern islands, explaining the slight difference in glacio-isostatic depression. Other subtidal deposits were dated on the Cap-aux-Meules Island between 21 and 18 ka (GaletPlat site) at an elevation of $\sim+5 \mathrm{~m}$ (Table 6). According to Stanford et al. (2011), the global sea-level passed from 120 to $110 \mathrm{~m}$ between these ages, meaning a glacioisostatic depression between 125 and $115 \mathrm{~m}$ from 21 to $18 \mathrm{ka}$ (Fig. 10). Still based on subtidal deposits and the global sea-level curve of Stanford et al. (2011), around $15 \mathrm{ka}$ (Fatima site), the crustal depression was about $100 \mathrm{~m}$ and around $11 \mathrm{ka}$ (Airport site), 55 m (Fig. 10; Table 6). For the northern archipelago, the scenario is slightly different since the deglaciation occurred later, i.e. between $19.8 \pm 1.4$ and $15.1 \pm 1.1 \mathrm{ka}$. The $15 \mathrm{ka}$ deposit is exposed at an elevation of $+16 \mathrm{~m}$ and suggests a crustal depression $>110 \mathrm{~m}$ 
(Fig. 10; Table 6). Other deposits dated to $13 \mathrm{ka}$ at the PAL-north site (+18 m), $12 \mathrm{ka}$ at the Sandcove site (+16 m), $11 \mathrm{ka} \mathrm{(+12} \mathrm{m)} \mathrm{and} 10 \mathrm{ka} \mathrm{(+13} \mathrm{m)} \mathrm{at} \mathrm{the} \mathrm{Seacow} \mathrm{site} \mathrm{indicate} \mathrm{a}$ glacio-isostatic depression from approximately $90 \mathrm{~m}$ to $50 \mathrm{~m}$ between 13 and $10 \mathrm{ka} \mathrm{(Fig.}$ 10; Table 6).

Notwithstanding the error on the ages and the uncertainty regarding the water depth of each sample at deposition, general trends regarding the glacio-isostatic adjustment on the Magdalen Islands can be discussed. Globally, the glacio-isostatic depression was more important on the southern archipelago, i.e. on the Entry and HavreAubert Islands, which were glaciated by the Escuminac ice-cap, an extensive glacier that originated from the northwestern Gulf of St. Lawrence. As soon as the northern archipelago was deglaciated, the depression seems to have followed the glacio-isostatic rebound of the southern archipelago, i.e., that at $~ 15 \mathrm{ka}$, the crustal depression was around $110 \mathrm{~m}$, similar to the depression on the central and southern islands for the same period (Fig. 10). However, the rebound took place more rapidly than the southern archipelago, which might be explained by the glaciation of the northern archipelago by the Newfoundland ice-cap (Rémillard et al. 2016); the ice thickness might have been less important than the Escuminac ice-cap on the southern islands. The central islands have experienced a less significant glacio-isostatic depression. Despite these small nuances between the islands, around 10-11 ka, the glacio-isostatic depression seems to have reached an equal level for the entire archipelago, i.e. $~ 50 \mathrm{~m}$ (Fig. 10). Rémillard et al. (2016) indicated that the RSL passed below the modern level just prior to $10.7 \mathrm{ka}$ cal. BP based on a terrestrial peat observed at the modern sea-level (grey plus symbols in Fig. 
9A), consistent with a glacio-isostatic depression of $\sim 50 \mathrm{~m}$. The age of $\sim 9.8 \mathrm{ka}$ cal. BP at $17 \mathrm{~m}$ depth suggests that the RSL was necessarily lower than $-17 \mathrm{~m}$ at that time but it is impossible to speculate on the exact depth (Fig. 9A; Rémillard et al. 2016).

The spatial variability in RSL at the Magdalen Islands scale is hardly comparable with regional literature since the differences seem to be observable as soon as the islands were deglaciated, i.e. before $\sim 16 \mathrm{ka}$; RSL reconstructions in the Maritime Provinces are rarely older than 16 ka (e.g. Shaw et al. 2002). However, this variability could be compared with studies on newly deglaciated areas even if the deglaciation occurred later. Spatial variability in RSL on small areas has been recognised in Newfoundland where over a short distance, the RSL scenario passes from a constant emergence on the Northern Peninsula to a J-shaped curve in the St. George Bay area (west) and the bay of Exploits (east) (Shaw et al. 2002; Bell et al. 2003, 2005). Consequently, the crustal depression recorded in the Northern Peninsula area is almost the double that over central Newfoundland; this is explained by the greater ice-loading by the LIS to the north compared to the smaller loading of the regional Newfoundland ice-cap (Bell et al. 2005). The variability within the Magdalen Island, i.e. north versus south, might be explained by the different ice-loading of the Escuminac ice-cap compared to the lobe from the Newfoundland ice-cap. Spatial variability is also recorded on the northeastern coast of United-States where the RSL scenario passes from a constant submergence to a J-shaped curve scenario from New-York City to Wells (Maine) owing to their respective distance to the ice-margin (LIS), i.e. from the peripheral forebulge to more inner ice, respectively (e.g. Gehrels et al. 1996; Shaw et al. 2002). Spatial and temporal variability also exists 
within the J-shaped curve scenario. Kelley et al. (2011) specified that between 16 and 12 cal. ka BP, the RSL fell from +70 to $-60 \mathrm{~m}$ in the Gulf of Maine, suggesting that the lowstand occurred earlier than what we observe in the Magdalen Islands. Barnhardt et al. (1995) associated this significant decrease in RSL with the very rapid passage of the forebulge after the deglaciation. On the inner Scotian Shelf, the RSL lowstand reached $65 \mathrm{~m}$ around $13 \mathrm{cal}$. ka BP (11.6 uncal. ka BP) (Stea et al. 1994, 1998). On the western coast of Newfoundland, the RSL passed below modern level at 12.6 \pm 0.2 cal. ka BP (10.6 uncal. ka BP), and decreased to -25 m below the modern level around 10.6 \pm 0.1 cal. ka BP (9.4 uncal. ka BP). The lowstand would have reached $-30 \mathrm{~m}$ in the southern Newfoundland (Shaw \& Forbes 1995). On Prince Edward Island (PEI), the lowstand reached approximately $-42 \mathrm{~m}$ between 9.5 and 9 ka cal. BP (Parkes et al. 2002). As the forebulge migrated inland, towards the retreating ice, it would be expected that the associated lowstands in Atlantic Canada occurred more lately roughly from south to north. Our data on the Magdalen Islands, i.e. the decrease of the RSL below modern level just prior to $10.7 \mathrm{ka}$ cal. $\mathrm{BP}$ and the lowstand around $10 \mathrm{ka}$ cal. BP, are completely consistent with this expected general trend. However, the depth reached by the lowstand is unknown but would be believed to have stand somewhere between -30 m (southern Newfoundland) and -42 m (PEI). Several studies have reported submerged geomorphic indicators attesting to a maximum depth of the lowstand (between $\sim 36$ and $200 \mathrm{~m}$ ) for the Magdalen Islands and surroundings area, but the timing of their formation remains unclear and they do not provide the precision necessary for RSL reconstructions (e.g. Sanschagrin 1964; Loring \& Nota 1966, 1973; Josenhans \& Lehman 1999; Audet-Morin 2010). 


\subsection{Holocene relative sea-level (RSL)}

After the evidence of a lowstand at $~ 9.8 \mathrm{ka}$ cal. BP around the Magdalen Islands, there is a lack of data until the late Holocene and this is generally true for the Maritime Provinces. One exception is the study of Parkes et al. (2002) who state that following the lowstand, the RSL rose rapidly from $8.6 \mathrm{ka}$ cal. BP at rates of $12 \mathrm{~mm} / \mathrm{yr}$ until $7.8 \mathrm{ka}$ cal. BP, to decelerate progressively until 6 ka cal. BP. For the late Holocene, two types of indicator observed on the archipelago allow us to draw a curve for the last 2,000 years (Fig. 9A). The terrestrial indicators documented by Juneau (2012) indicate a lower RSL than their modern elevation, i.e. below modern level, although it is not possible to correlate them to an exact past mean sea-level. However, sediments suggesting higher RSL and now located below modern sea-level were observed in the cores collected at the Hospital Pond and BAH sites, and also at Les Sillons site presented by Rémillard et al. (2015a) (Fig. 9A). The RSL curve is therefore constrained between the marine sediments and the terrestrial indicators of Juneau (2012). According to Juneau (2012) and Barnett et al. (2017), the RSL increased by $3 \mathrm{~m}$ from $2 \mathrm{ka}$ BP to present day with a submersion rates between 1.3 to $2.0 \mathrm{~mm} / \mathrm{yr}$ with a deceleration between 1 to $0.5 \mathrm{ka}$ BP. More precisely, the RSL increased with a submersion rate of $20.7 \mathrm{~cm} /$ century between 1 and 0.8 ka BP (2.1 $\mathrm{mm} / \mathrm{yr}), 17.9 \mathrm{~cm} /$ century between 0.8 and $0.6 \mathrm{ka}$ BP $(1.8 \mathrm{~mm} / \mathrm{yr})$, and $15.8 \mathrm{~cm} / \mathrm{century}$ between 0.6 and 0.2 ka BP (1.6 mm/yr). For comparison, New Brunswick coastlines have been affected by a RSL rise of $10 \mathrm{~cm} /$ century since $3 \mathrm{ka}$ BP (Scott et al. 1995; Gehrels et al. 2004). On PEI, the suggested RSL for the last three millennia on the entire island increases from west to east (Krank 1972; Scott et al. 1981). Different submersion rates were calculated for different sites: $8 \mathrm{~cm} /$ century for the western end of the island, 9 
$\mathrm{cm} /$ century for the centre-south, $14 \mathrm{~cm} /$ century for the southeast, and $19 \mathrm{~cm} /$ century for the northeast side. On the Atlantic coast of Nova Scotia (Chezzetcook Inlet), a RSL rise of $22 \mathrm{~cm} /$ century has been proposed for the last 2 ka BP (Scott et al. 1995; Gehrels et al. 2004). According to Gehrels et al. (2004), the higher rates of RSL rise in Nova Scotia are mostly due to the crustal subsidence caused by forebulge migration and collapse, but also partly by the ocean loading on the Scotian shelf. The rates of RSL rise measured on the Magdalen Islands vary between 21 and $16 \mathrm{~cm} /$ century for the last $2 \mathrm{ka} \mathrm{BP}$; these are higher than those measured for the New Brunswick coasts but lower than in Nova Scotia. Although the entire region is affected by the crustal subsidence caused by the collapse of the migrating forebulge, the differences from one area to another might be explained by a more important ocean loading in the Gulf of St. Lawrence compared to that near the coasts of New Brunswick, in turn explaining higher rates on the northeast PEI and the Magdalen Islands compared to the eastern PEI and the New Brunswick coasts. In the same way and as suggested by Gehrels et al. (2004), a more important ocean loading on the Scotian shelf would explain the higher rates of RSL rise on the Atlantic coasts of Nova Scotia compared to the Magdalen archipelago.

\subsection{New insights for the MIS 4 - MIS 3 interval}

The new sedimentological and chronological data presented in this paper also provide new information on the last interstadial period. The stratigraphic sequence at the Cap Blanc (Entry Island) exposes very shallow marine sediment (subtidal) evolving into shallow marine, and then littoral systems, and is interpreted as a transgressive period during a high RSL. This marine/littoral sequence is truncated and topped by cryopediment deposits suggesting periglacial conditions at deposition. The five 
luminescence ages obtained from the entire sequence range between $65 \pm 5$ ka (OSL57) and $51 \pm 4$ ka (OSL55); these ages are all consistent with the average of $57 \pm 4 \mathrm{ka}$. It appears that the entire sequence was deposited during a higher RSL, at least $\sim+35 \mathrm{~m}$ since the littoral sediment stood at this elevation, at the end of the MIS 4 or the onset of the MIS 3. Rémillard et al. (2013) presented radiocarbon ages between 45 and 50 ka BP at +15 m from a terrestrial peat located on the Havre-Aubert Island (ACE site). These ages were corroborated by two luminescence ages of $41 \pm 4$ ka (OSL03) and $44 \pm 4$ ka (OSL04) (Table 6; Rémillard et al. 2016). The littoral unit and terrestrial peat sequence is topped by a periglacial colluvial deposit, similar to those observed on the Entry Island. The model of Stea et al. (2011) suggests a glaciation of the Maritime Provinces of eastern Canada during the MIS 4 (Caledonia Phase) and a retreat phase during the MIS 3 ( 50-25 ka) with the existence of a calving bay along the Laurentian Channel up to the Anticosti Island. The type section presented in Stea et al. (2011) is the Bay St. Lawrence in northern Cap Breton (Nova Scotia) where at 20-30 m a.s.l., a glaciomarine deposit formed on an isostatically depressed Earth's crust. Shells from this deposit have been dated between $\sim 60$ and $40 \mathrm{ka}$ cal. BP. The ages, elevation and interpretation of this stratigraphical unit strongly suggest that it is analogous to the deposit at the Cap Blanc site. However, according to their model, the Magdalen Islands remained ice-covered during the entire MIS 3. Our data rather suggest that the Magdalen archipelago was icefree between $\sim 57 \pm 4$ ka and $41 \pm 4$ ka (OSL03). Many studies support the scenario of a much wider calving bay penetrating deep into the LIS in the Laurentian Channel during the MIS 3. For instance, Dionne \& Occhietti (1996) obtained ages between 38 and 33 ka cal. BP (35 and 29 ka uncal. BP) in sand containing shell fragments near Tadoussac 
(Québec) located in the St. Lawrence Estuary. On the Île-aux-Coudres (Québec), also located in the St. Lawrence Estuary, Brodeur \& Allard (1985) obtained four finite radiocarbon ages of between 39 and $31 \mathrm{ka} \mathrm{cal.} \mathrm{BP} \mathrm{(34} \mathrm{and} 26 \mathrm{ka}$ uncal. BP) on organic peat detritus collected in fluvial sediments. Ages of between 33 and 31 ka cal. BP were obtained on plant fragments from the St. Lawrence Lowlands, which is even further into the St. Lawrence River (Parent et al. 2015). These studies, amongst others, indicate that the calving bay in the Laurentian Channel opened much further into the St. Lawrence Estuary than previously suggested by Stea et al. (2011).

The data presented above sketch for the first time a partial RSL curve for the interval between the end of the MIS 4 and the MIS 3 period (Fig. 9B). It seems that the scenario was similar to the curve established for the LGM to early Holocene period, i.e. that a RSL of $+35 \mathrm{~m}$ high decreased to +10 to $+15 \mathrm{~m}$ above modern sea-level in approximately 15 kyr. According to the compilation of Caputo (2007) and Siddall et al. (2008), global sea-level stood somewhere between 100 and $50 \mathrm{~m}$ below current level at $\sim 60 \mathrm{ka}$. This broad range is due to the existence of several global sea-level curves for that period and comprises the possible sea-level oscillations within the MIS 3. Since the littoral deposit is located at $+35 \mathrm{~m}$ on the Entry Island, this would imply a crustal depression of between at least 85 and $135 \mathrm{~m}$. Global sea-level remained roughly between 100 and 50 m below modern level until 30 ka (Caputo 2007; Siddall et al. 2008). Therefore, the littoral deposit located at $+15 \mathrm{~m}$ on the Havre-Aubert Island and dated to 45 ka suggests a rebound of between 20 and $70 \mathrm{~m}$, depending on the global sea-level values used, between roughly 60 and $45 \mathrm{ka}$. Although there is no evidence of an MIS 4 
glaciation on the Magdalen Islands, it is generally accepted in the literature that the entire Maritime Provinces of eastern Canada were covered by glacial ice during that period (e.g. Dredge et al. 1992; Stea et al. 1998, 2011), and thus the MIS 3 crustal depression is very likely to have a glacio-isostatic origin. Ó Cofaigh et al. (2012) and Gallagher et al. (2015) also present many OSL ages from the late MIS 4 - MIS 3 interval on the other side of the Atlantic from raised beaches along the south coast of Ireland. Gallagher et al. (2015) suggested that southern Ireland experienced episode(s) of deglaciation, periglacial conditions (colluvial deposits), and sufficient glacio-isostatic subsidence $(45-75 \mathrm{~m})$ to allow a local positive RSL ( $+5 \mathrm{~m})$. This scenario is very similar to the Magdalen Islands and suggests that the relative retreat of glaciers, the periglacial conditions, and the high RSL caused by glacio-isostatic depression phase during the late MIS 4 - MIS 3 interval might be pan-Atlantic for the coastal regions that experienced partial deglaciation.

\subsection{Data from the MIS 5}

The uncertainties on the MIS 5 ages acquired at the Bassin and Camping sites do not allow us to correlate the deposits to a specific global sea-level. However, the age of $115 \pm 8 \mathrm{ka}$ at the Camping site is easily consistent with the MIS 5e highstand. The elevation is also similar to the Portage du Cap stratigraphical sequence described by Dredge et al. (1992) where the basal unit is interpreted as beach gravel deposited on a $+14 \mathrm{~m}$ high sandstone platform bored with holes identical to those formed in the present intertidal zone. Dredge et al. (1992) correlated this beach unit to the MIS 5e based on palynological and macro- and micro-fossils analyses, during a high RSL. No absolute ages were acquired from this sequence. 
The available literature on the MIS 5e highstand suggests values of +2 up to $+9 \mathrm{~m}$ between 132 and 116 ka (e.g. Caputo 2007; Rohling et al. 2008; O’Leary et al. 2013). The data point at the Camping site $(+15 \mathrm{~m})$ suggests a glacio-isostatic depression of $\sim 10$ m, presumably associated with the MIS 6 glaciation that occurred in eastern Canada (e.g. Stea et al. 2011). This depression is much less significant compared to those estimated for the post-LGM period, but as the MIS 5e corresponds to the last interglacial climax, it is likely that deglaciation and the GIA of the area occurred sometime before. At the Bassin site, located at the modern high tide level (Fig. 3), Dredge et al. (1992) associated the deposit with the MIS 5e based on pollen profiles and the presence of oysters shells (Ostrea virginica), indicating warm conditions (interglacial). Consequently, they interpreted their U/Th ages (106.4 $\pm 8.2 \mathrm{ka}, 101.7 \pm 15.6 \mathrm{ka}$, and $89 \pm 7.6 \mathrm{ka}$; cf. Reliability of the luminescence ages section) as a minimum. At the upper limit of $+2 \sigma$, our pIRIR 290 age of $92 \pm 8 \mathrm{ka}$ is also closer to the MIS $5 \mathrm{e}$ and is therefore in better agreement with both the palaeoecological data of Dredge et al. (1992) and the GIA that continued after the deposition of the Camping site unit (suggesting a glacio-isostatic rebound of $\sim 15 \mathrm{~m}$ ).

\subsection{Implications for ice sheet modelling}

The influence of ice-sheets in the GIA models of Koohzare et al. (2008) and Peltier et al. (2015) is based on the glaciation model of Dyke (2004) and Dyke et al. (2002), respectively. For Atlantic Canada, results from these models suggest that the LIS reached its maximum, approximately up to the continental slope, prior to the LGM and remained at this limit well after the LGM with large-scale ice margin retreat starting well after $\sim 17.2 \mathrm{ka}$ cal. BP. This scenario is in conflict with the recent glacial modelling of Shaw et al. (2006) and Stea et al. (2011), which indicate a glaciation of the Maritime Provinces by 
the Appalachian Glacier Complex, i.e. by different ice-caps coalescing with each other and the LIS that formed an ice stream in the Laurentian Channel. This latter scenario is supported by recent data from Rémillard et al. (2016) suggesting that the Magdalen Islands were glaciated by two ice-caps during the LGM. Finally, the timing of the deglaciation suggested by Dyke et al. (2002) is different from the study of Rémillard et al. (2016) and the data presented in this paper, both of which support open waters for at least a part of the Laurentian Channel and the southern Magdalen Islands as early as 20$25 \mathrm{ka}$. The ice loading and the well-constrained timing of ice retreat are crucial information to take into account in GIA models (e.g. Goslin et al. 2015; Peltier et al. 2015). The apparent overestimation of subsidence for the Maritime Provinces of eastern Canada suggested by the comparison of the GIA models and the measured subsidence rates may be related to the use of inaccurate data on the glacial and deglacial history. In addition, the peripheral forebulge induced by regional ice-caps might be smaller than that from the LIS because of the greater ice thickness of the latter. Consequently, the subsidence values resulting of the migration of the peripheral forebulge would be greater for the regions affected by the LIS. Thus the model of Dyke et al. (2002), suggesting a glaciation of the Maritimes by the LIS, might overestimate the resulting forebulge amplitude and so the predicted modern vertical land motion rates.

\section{Conclusions}

The new sedimentological and chronological data for the Magdalen Islands presented in this study allow the reconstruction of a more detailed RSL curve for the LGM to the late Holocene ( 25 to $0.5 \mathrm{ka}$ ), as well as a partial curve for the period between the late MIS 4 
to the MIS 3 ( 60 to $40 \mathrm{ka}$ ). Although there is an important lack of data between $9.8 \mathrm{ka}$ cal. BP and the late Holocene, the data distribution indicates that the post-LGM RSL scenario for the Magdalen Islands follows a J-shaped type curve; an initial high RSL was followed by a gradual decrease (depth of $>17 \mathrm{~m}$ ) and finally an emergence due to the glacio-isostatic rebound and the migrating forebulge. This in turn was followed by a constant submergence because of the forebulge collapse and the continuing glacioisostatic rebound. However, the glacio-isostatic depression curve proposed for the LGM to the early Holocene period suggests that until $\sim 11-10 \mathrm{ka}$, there were a few local differences in crustal depression, probably associated with the distinct glacial history of the southern, central and northern islands. For the late Holocene, the RSL curve is constrained by terrestrial and marine indicators revealing that the RSL has risen by at least $3 \mathrm{~m}$ during the last two millennia. This RSL rise is mainly attributed to the ongoing GIA (peripheral forebulge collapse) and partly to the hydro-isostasy induced by the increasing ocean depth. The luminescence ages from the transition between late MIS 4 and MIS 3 allow the reconstruction of a partial RSL curve that, when compared to global sea-level, suggests a GIA following the MIS 4 glaciation, a scenario similar to the postLGM.

This study presents RSL data for a broad timescale, i.e. from MIS 5 to the late Holocene, and provides evidence for two different glacial/interglacial (or interstadial) transitions. Despite the uncertainties associated with the ages and with the linking of the indicators to an accurate former RSL, this study represents a significant contribution to the RSL dataset of the Gulf of St. Lawrence; it constitutes a major input of empirical data 
to the regional GIA and RSL modelling effort of eastern Canada. In the context of the modern climate change, these precisions are essential to develop accurate projections on future sea-level variations as overestimated subsidence rates based on GIA models can lead to the overvaluation of the RSL rise in formerly glaciated areas such as eastern Canada.

\section{Acknowledgements}

Gabriel Ladouceur is thanked for its help in the field, as well as Marie-Pier St-Onge, Jacques Labrie, Elissa Barris and Quentin Beauvais for their help in the laboratory. David Noël is thanked for its valuable help during the vibrocoring fieldwork. The authors wish to acknowledge the support of technical staff of the Nordic Laboratory for Luminescence

Dating (NLL). The Natural Sciences and Engineering Research Council of Canada (NSERC), Fonds de recherche du Québec Nature et Technologies (FQRNT), the Coastal Geoscience Chair, and the Canada Research Chair in Marine Geology provided financial support for the project.

\section{References}

Aitken, M.J. 1985. Thermoluminescence Dating. 359 pp. Academic Press Inc., London.

Audet-Morin, M. 2010. Géomorphologie marine des zones extracôtières est et sud des Îles-de-la-Madeleine, Québec. M.Sc. thesis, Université Laval, 57 pp.

Barnett, R. L., Bernatchez, P., Garneau, M. \& Juneau, M.-N. 2017. Reconstructing late Holocene relative sea-level changes at the Magdalen Islands (Gulf of St. Lawrence, Canada) using multi-proxy analyses. Journal of Quaternary Science. 
Barnhardt, W.A., Gehrels, W.R., Belknap, D.F. \& Kelley, J.T. 1995. Late Quaternary relative sea-level change in the western Gulf of Maine: evidence for a migrating glacial forebulge. Geology 23, 317-320.

Bell, T., Batterson, M.J., Liverman, D.G.E. \& Shaw, J. 2003. A new late-glacial sealevel record for St.George's Bay, Newfoundland. Canadian Journal of Earth Sciences 40, 1053-1070.

Bell, T., Daly, J., Batterson, M.J., Liverman, D.G.E., Shaw, J. \& Smith, I. R. 2005. Late Quaternary relative sea-level change on the west coast of Newfoundland. Géographie physique et Quaternaire 59, 129-140.

Bernatchez, P., Dubois, J-M.M. 2004. Bilan des connaissances de la dynamique de l'érosion des côtes du Québec maritime laurentien. Géographie physique et Quaternaire $58,45-71$.

Bernatchez, P., Drejza, S., Dugas, S. 2012. Marges de sécurité en érosion côtière : évolution historique et future du littoral des îles de la Madeleine. Laboratoire de dynamique et de gestion intégrée des zones côtières, Université du Québec à Rimouski. Rapport remis au ministère de la Sécurité publique du Québec, 71 p.

Bigras, P. \& Dubois, J.-M.M. 1987. Répertoire commenté des datations 14C du nord et du sud de l'estuaire du Saint-Laurent, Québec et Labrador. Université de Sherbrooke, Département de Géographie, Bulletin de recherche, 160 p.

Blott, S.J. \& Pye, K. 2001. Gradistat: a grain size distribution and statistics package for the analysis of unconsolidated sediments. Earth Surface Processes and Landforms 26, $1237-1248$.

Bøtter-Jensen, L., Thomsen, K. \& Jain, M. 2010. Review of optically stimulated luminescence (OSL) instrumental developments for retrospective dosimetry. Radiation Measurements 45, 253-257.

Brisebois, D. 1981. Lithostratigraphie des strates Permo-Carbonifères de l'archipel des Îles de la Madeleine. 48 pp. Ministère de l'Énergie et des Ressources du Québec, Québec, DPV-796, Québec.

Brodeur, D., and Allard, M. 1985. Stratigraphie de l'île aux Coudres, estuaire moyen du Saint-Laurent, Québec. Géographie physique et Quaternaire 39, 183-197.

Candy, I., Schreve, D.C., Sherriff, J. \& Tye, G.J. 2014. Marine Isotope Stage 11: Palaeoclimates, palaeoenvironments and its role as an analogue for the current interglacial. Earth-Science Reviews 128, 18-51.

Caputo, R. 2007. Sea-level curves: Perplexities of an end-user in morphotectonic applications. Global and Planetary Change 57, 417-423. 
Cazenave, A. \& Le Cozannet, G. 2014. Sea-level rise and its coastal impacts, Earth's Future 2, 15-34.

Chapot, M.S., Roberts, H.M., Duller, G.A.T. \& Lai, Z.P. 2012. A comparison of naturaland laboratory-generated dose response curves for quartz optically stimulated luminescence signals from Chinese Loess. Radiation Measurements 47, 1045-1052.

Church, J.A., Clark, P.U., Cazenave, A., Gregory, J.M., Jevrejeva, S., Levermann, A., Merrifield, M.A., Milne, G.A., Nerem, R.S., Nunn, P.D., Payne, A.J., Pfeffer, W.T., Stammer, D. \& Unnikrishnan, A.S. 2013. Sea-level Change. In: Stocker, T.F., Qin, D., Plattner, G.-K., Tignor, M., Allen, S.K., Boschung, J., Nauels, A., Xia, Y., Bex, V., \& Midgley, P.M. (eds.). Climate Change 2013: The Physical Science Basis. Contribution of Working Group I to the Fifth Assessment Report of the Intergovernmental Panel on Climate Change. Cambridge University Press, Cambridge, United Kingdom and New York, NY, USA.

Cunningham, A.C. \& Wallinga, J. 2010. Selection of integration time intervals for quartz OSL decay curves. Quaternary Geochronology 5, 657-666.

Dionne, J.-C., and Occhietti, S. 1996. Aperçu du Quaternaire a` l'embouchure du Saguenay, Québec. Géographie physique et Quaternaire 50, 5-34.

Drapeau, G., Mercier, O. 1990. Modélisation de l'évolution du littoral des îles de la Madeleine, Québec. Géographie physique et Quaternaire 44, 217-226.

Dredge, L.A., Mott, R.J. \& Grant, D.R. 1992. Quaternary stratigraphy, paleoecology, and glacial geology, Iles de la Madeleine, Québec. Canadian Journal of Earth Science 29, 1981-1996.

Duller, G.A.T. 2003. Distinguishing quartz and feldspar in single grain luminescence measurements. Radiation Measurements 37, 161-165.

Dyke, A.S. 2004. An outline of North American deglaciation with emphasis on central and northern Canada. In: Ehlers, J., Gibbard, P.L. (Eds.), Quaternary GlaciationsExtent and Chronology, Part 2, North America. Elsevier.

Dyke, A.S. \& Peltier, W.R. 2000. Forms, response times and variability of relative sealevel curves, glaciated North America. Geomorphology 32, 315-333.

Dyke, A.S. Andrews, J.T. Clark, P.U. England, J.H. Miller, G.H. Shaw, J. \& Veillette, J.J. 2002. The Laurentide and Innuitian ice sheets during the last glacial maximum. Quaternary Science Reviews 21, 9-31.

Folk, R.L. \& Ward, W.C. 1957. Brazos River bar: a study in the significance of grain size parameters. Journal of Sedimentary Petrology 27, 3-26. 
Gallagher, C., Telfer, M.W. \& Ó Cofaigh, C. 2015. A marine isotope stage 4 for Pleistocene raised beach deposits near Fethard, southern Ireland. Journal of Quaternary Science 30, 754-763.

Gehrels, W.R. 2010. Late Holocene land- and sea-level changes in the British Isles: implications for future sea-level predictions. Quaternary Science Reviews 29, 1648-1660.

Gehrels, W.R, Belknap, D.F. \& Kelley, J.T. 1996. Integrated high-precision analyses of Holocene relative sea-level changes: lessons from the coast of Maine. Geological Society of American Bulletin 108, 1073-1088.

Gehrels, W.R., Milne, G.A., Kirby, J.R., Patterson, R.T. \& Belknap, D.F. 2004. Late Holocene sea-level changes and isostatique crustal movements in Atlantic Canada. Quaternary International 120, 79-89.

Giles, P.S. 2008. Windsor Group (Late Mississippian) stratigraphy, Magdalen Islands, Quebec: a rare eastern Canadian record of late Visean basaltic volcanism. Atlantic Geology 144, 167-185.

Goslin, J., Van Vliet Lanoë, B., Spada, G., Bradley, S., Tarasov, L., Neill, S. \& Suanez, S. 2015. A new Holocene relative sea-level curve for western Brittany (France): Insights on isostatic dynamics along the Atlantic coasts ofnorth-western Europe. Quaternary Science Reviews 129, 341-365.

Hansen, V., Murray, A.S., Buylaert, J.-P., Yeo, E.Y. \& Thomsen, K.J. 2015. A new irradiated quartz for beta source calibration. Radiation Measurements 81, 123-127.

Jevrejeva, S., Grinsted, A. \& Moore, J.C. 2014. Upper limit for sea-level projections by 2100. Environmental Research Letters 9, 104008.

Josenhans, H. 2007. Atlas of the marine environment and seabed geology of the Gulf of St. Lawrence. Geological Survey of Canada, File 5346.

Josenhans, H. \& Lehman, S. 1999. Late glacial stratigraphy and history of the Gulf of St. Lawrence, Canada. Canadian Journal of Earth Sciences 36, 1327-1345.

Juneau, M.-N. 2012. Hausse récente du niveau marin relatif aux Îles-de-la-Madeleine. Mémoire de maîtrise, Université du Québec à Rimouski, Département de biologie, chimie et géographie, $161 \mathrm{p}$.

Kelley, A.R., Kelley, J.T., Belknap, D.F. \& Gontz, A.M. 2011. Coastal and terrestrial impact of the isostatically forced Late Quaternary drainage divide shift, Penobscot and Kennebec Rivers, Maine, USA. Journal of Coastal Research 27, 1085-1093.

Koohzare, A. Vanicek, P. \& Santos, M. 2008. Pattern of recent vertical crustal movements in Canada. Journal of Geodynamics 45, 133-145. 
Krank, K. 1972. Geomorphological Development and Post-Pleistocene Sea-level Changes, Northumberland Strait, Maritime Provinces. Canadian Journal of Earth Sciences 9, 835-844.

Lambeck, K. \& Chappell, J. 2013. Sea level chance through the Last Glacial cycle. Science 292, 679-686.

Lambeck, K., Woodroffe, C.D., Antonioli, F., Anzidei, M., Gehrels, W.R., Laborel, J. \& Wright, A.J. 2010. Paleoenvironmental Records, Geophysical Modeling, and Reconstruction of Sea-Level Trends and Variability on Centennial and Longer Timescales. In Church, J. A., Woodworth, P. L. \& Stanley W. (eds.): Understanding sealevel rise and variability, 61-121. John Wiley \& Sons, United Kingdom.

Lambeck, K., Rouby, H., Purcell, A., Sun, Y. \& Sambridge, M. 2014. Sea-level and global ice volumes from the Last Glacial Maximum to the Holocene. Proceedings of the National Academy of Sciences 111, 15296-15303.

Loring, D. \& Nota, D. 1966. Sea-floor conditions around the Magdalen Islands in the southern Gulf of St. Lawrence. Journal of the Fisheries Research Board of Canada 23, 1197-1207.

Loring, D. \& Nota, D. 1973. Morphology and sediments of the Gulf of St. Lawrence. Service des pêches et des sciences de la mer, Bulletin 182, 147 pp.

Murray, A.S. \& Olley, J.M. 2002. Precision and accuracy in the optically stimulated luminescence dating of sedimentary quartz: a status review. Geochronometria 21, 1-16.

Murray, A.S. \& Wintle, A.G. 2000. Luminescence dating of quartz using an improved single-aliquot regenerative-dose protocol. Radiation Measurement 32, 57-73.

Murray, A.S. \& Wintle, A.G. 2003. The single aliquot regenerative dose protocol: potential for improvements in reliability. Radiation Measurement 37, 377-381.

Murray, A.S., Marten, R., Johnston, A. \& Martin, P. 1987. Analysis for naturally occurring radionuclides at environmental concentrations by gamma spectrometry. Journal of Radioanalytical and Nuclear Chemistry 115, 263-288.

Murray-Wallace, C.V. \& Woodroffe, C.D. 2014. Quaternary Sea-Level Changes. A global perspective. Cambridge University Press, Cambridge, 504 pp.

Ó Cofaigh, C., Telfer, M.W., Bailey, R.M. \& Evans, D.J.A. 2012. Late Pleistocene chronostratigraphy and ice sheet limits, southern Ireland. Quaternary Science Reviews 44, 160-179. 
O’Leary, M.J., Hearty, P.J., Thompson, W.G., Raymo, M.E., Mitrovica, J.X. \& Webster, J.M. 2013. Ice sheet collapse following a prolonged period of stable sea level during the last interglacial. Nature Geoscience 6, 796-800.

Paquet, G. 1989. L’évolution de la plate-forme gréseuse de l'Île du Cap-aux-Meules (Îles-de-la-Madeleine, Québec). M.Sc. thesis, Université de Montréal, 223 pp.

Parent, M., Lefebvre, R., Rivard, C., Lavoie, M. \& Guilbault, J.-P. 2015. MidWisconsinan fluvial and marine sediments in the central St. Lawrence lowlands implications for glacial and deglacial events in the Appalachian uplands. The Geological Society of America, Northern Section - 50 ${ }^{\text {th }}$ Annual meeting, paper no. 31-2.

Parkes, G.S., Forbes, D.L. \& Ketch, L.A. 2002. Sea-level rise In McCulloch, M.M., Forbes, D.L., Shaw, R.D. and the CCAF A041 Scientific Team. Coastal impacts of climate change and sea-level rise on Prince Edward Island. Geological Survey of Canada, Open File 4261.

Peltier, W.R., Argus, D.F. \& Drummond, R. 2015. Space geodesy constrains ice age terminal deglaciation: The global ICE-6G_C (VM5a) model. Journal of Geophysical Research: Solid Earth 120, 450-487.

Prescott, J.R. \& Hutton, J.T. 1994. Cosmic ray contributions to dose rates for luminescence and ESR dating: large depths and long-term time variations. Radiation Measurements 23, 497-500.

Quinlan, G. \& Beaumont, C. 1981. A comparison of observed and theoretical postglacial relative sea-level in Atlantic Canada. Canadian Journal of Earth Sciences 18, 11461163.

Reimer, P.J., Bard, E., Bayliss, A., Beck, J.W., Blackwell, P.G., Ramsey, C.B., Buck, C.E., Cheng, H., Edwards, R.L., Friedrich, M., Grootes, P.M., Guilderson, T.P., Haflidason, H., Hajdas, I., Hatte, C., Heaton, T.J., Hoffmann, D.L., Hogg, A.G., Hughen, K.A., Kaiser, K.F., Kromer, B., Manning, S.W., Niu, M., Reimer, R.W., Richards, D.A., Scott, E.M., Southon, J.R., Staff, R.A., Turney, C.S.M. \& van der Plicht, J. 2013: INTCAL13 and MARINE13 radiocarbon age calibration curves 0-50,000 years cal BP. Radiocarbon 55, 1869-1887.

Rémillard, A.M., Hétu, B., Bernatchez, P. \& Bertran, P. 2013. The Drift des Demoiselles on the southern Magdalen Islands (Quebec, Canada): sedimentological and micromorphological evidence of a glacial diamict of Late Wisconsinan. Canadian Journal of Earth Sciences 50, 545-563.

Rémillard, A.M., Buylaert, J.-P., Murray, A.S., St-Onge, G., Bernatchez, P. \& Hétu, B. 2015a. Quartz OSL dating of late Holocene beach ridges from the Magdalen Islands (Quebec, Canada). Quaternary Geochronology 30, 264-269. 
Rémillard, A.M., Hétu, B., Bernatchez, P., Buylaert, J.-P., Murray, A.S., St-Onge, G. \& Geach, M. 2015b. Chronology and palaeoenvironmental implications of the ice-wedge pseudomorphs and composite-wedge casts on the Magdalen Islands (eastern Canada). Boreas 44, 658-675.

Rémillard, A.M., St-Onge, G., Bernatchez, P. Hétu, B., Buylaert, J.-P., Murray, A.S. \& Vigneault, B. 2016. Chronology and stratigraphy of the Magdalen Islands archipelago from the last glaciation to the early Holocene: new insights into the glacial and sea-level history of eastern Canada. Boreas 45, 604-628.

Reynolds L.C. \& Simms, A.R. 2015. Late Quaternary relative sea-level in Southern California and Monterey Bay. Quaternary Science Reviews 126, 57-66.

Rohling, E.J., Grant, K., Hemleben, C., Siddall, M., Hoogakker, B.A.A., Bolshaw, M. \& Kucera, M. 2008. High rates of sea-level rise during the last interglacial period. Nature Geoscience 1, 38-42.

Sanschagrin, R. 1964. Magdalen Islands. Ministère de l'Énergie et Ressources du Québec, Geological Report 106, 57 pp.

Scott, D.B., Williamson, M.A. \& Medioli, F.S. 1981. Marsh foraminifera of Prince Edward Island: their recent distribution and application for former sea-level studies. Maritime Sediments and Atlantic Geology 17, 98-129.

Scott, D.B., Medioli, F.S. \& Duffett, T.E. 1984. Holocene rise of relative sea-level at Sable Island, Nova Scotia, Canada. Geology 12, 173-176.

Scott, D.B., Boyd, R., Douma, M., Medioli, F.S., Yuill, S., Leavitt, E. \& Lewis, C.F.M. 1989. Holocene relative sea-level changes and Quaternary glacial events on a continental shelf edge: Sable island bank, In Scott, D. B., Pirazolli, P. A. \& Honig, C. A. (eds.). Late Quaternary Sea-Level Correlation and Applications, Kluwer Academic Publishers, Dordrecht, pp. 105-119.

Scott, D.B., Gayes, P.T. \& Collins, E.S. 1995. Mid-Holocene precedent for a future rise in sea-level along the Atlantic coast of North America. Journal of Coastal Research 11, 615-622.

Shaw, J. \& Forbes, D.L. 1995. The postglacial relative sea-level lowstand in Newfoundland. Canadian Journal of Earth Sciences 32, 1308-1330.

Shaw, J., Gareau, P. \& Courtney, R.C. 2002. Palaeogeography of Atlantic Canada 13-0 kyr. Quaternary Science Reviews 21, 1861-1878.

Shaw, J., Piper, D.J.W., Fader, G.B.J., King, E.L., Todd, B.J., Bell, T., Batterson, M.J. \& Liverman, D.G.E. 2006. A conceptual model of the deglaciation of Atlantic Canada. Quaternary Science Reviews 25, 2059-2081. 
Siddall, M., Rohling, E.J., Thompson, W.G. \& Waelbroeck, C. 2008. Marine isotope stage 3 level fluctuations: data synthesis and new outlook. Reviews of Geophysics 46, RG4003.

Stanford, J.D., Hemingway, R., Rohling, E.J., Challenor, P.G., Medina-Elizade, M. \& Lester, A.J. 2011. Sea-level probability for the last deglaciation: A statistical analysis of far-field records. Global and Planetary Change 79, 193-203.

Stea, R.R. 2004. The Appalachian glacier complex in Maritime Canada. In Ehlers, J. \& Gibbard, P. L. (eds.): Quaternary glaciations - extent and chronology, part II: North America, 213-232. Elsevier, New York.

Stea, R.R., Boyd, R., Fader, G.B.J., Courtney, R.C., Scott, D.B. \& Pecore, S.S. 1994. Morphology and seismic stratigraphy of the inner continental shelf off Nova Scotia, Canada: evidence for a -65m lowstand between 11,650 and 11,250 C14 yr B.P. Marine Geology 117, 135-154.

Stea, R.R., Piper, D.J.W., Fader, G.B.J. \& Boyd, R. 1998. Wisconsinian glacial and sealevel history of Maritime Canada and the adjacent continental shelf: A correlation of land and sea events. Geological Society of America Bulletin 110, 821-845.

Stea, R.R., Seaman, A.A., Pronk, T., Parkhill, M.A., Allard, S. \& Utting, D. 2011. The Appalachian Glacier Complex in Maritime Canada. In Ehlers, J., Gibbard, P.L. (eds.): Quaternary glaciations - extent and chronology, part II: North America, 631-659. Elsevier, New York.

Tamisiea, M.E. \& Mitrovica, J.X. 2011. The moving boundaries of sea-level change. Understanding the origins of geographic variability. Oceanography, Special Issue 24(2), 24-39.

Thiel, C., Buylaert, J.-P., Murray, A.S., Terhorst, B., Hofer, I., Tsukamoto, S. \& Frechen, M. 2011. Luminescence dating of the Stratzing loess profile (Austria) - Testing the potential of an elevated temperature post-IR IRSL protocol. Quaternary International 234, 23-31.

Vigneault, B. 2012. Cadre lithostratigraphique quaternaire du nord des Îles-de-laMadeleine. M. Sc. thesis, Université du Québec à Rimouski, 109 pp.

Wintle, A. G. \& Murray, A. S. 2006. A review of quartz optically stimulated luminescence characteristics and their relevance in single-aliquot regeneration dating protocols. Radiation Measurements 41, 369-391.

Yokoyama, Y., Lambeck, K., De Deckker, P., Johnston, P. \& Fifield L.K. 2000. Timing of the Last Glacial Maximum from observed sea-level minima. Nature 406, 713-716. 


\section{Figure captions}

Fig. 1. Schematic representation of the three major theoretical postglacial relative sealevel curves in formerly glaciated areas.

Fig. 2. Location of the Magdalen Islands in eastern Canada and the Gulf of St. Lawrence. Sample sites are shown as black pins and coring sites as black asterisks.

Fig. 3. Comparison of luminescence (OSL and pIRIR 290 ) ages with U/Th ages for age control. A. Location of the Bassin site; the sampling site is located at modern sea-level. B. Representative picture of the lagoonal deposit (luminescence ages) and the overlying woody peat (U/Th ages; Dredge et al. 1992).

Fig. 4. A. Quartz OSL SAR growth curve from OSL53 (Cap Blanc site). Sensitivitycorrected regenerated signals are shown as filled circles, the unfilled circle represents a repeat point (recycling) and the open triangle the response to zero dose (recuperation). The sensitivity corrected natural OSL signal is interpolated onto the growth curve to give the equivalent dose, $\mathrm{D}_{\mathrm{e}}$ (in this case, 47.6 Gy). The inset illustrates a typical natural OSL decay from the same sample together with a decay curve of an aliquot of calibration quartz (dashed); a background signal from the end of the stimulation curve was subtracted before normalisation. B. Preheat plateau test carried out on sample OSL53 and OSL55; each point represents the average of 3 aliquots. The dashed line represents the average $D_{e}$ over the temperature range $160-200{ }^{\circ} \mathrm{C}$. C. Summary of dose recovery data for all aliquots $(n=54)$ of 7 samples measured with preheat of $200{ }^{\circ} \mathrm{C}$ for 10 s and cutheat of $160{ }^{\circ} \mathrm{C}$. Inset shows the measured doses plotted against the given doses.

Fig. 5. A. SAR pIRIR 290 growth curve from OSL51 (Camping site). Sensitivity-corrected regenerated points are shown as filled circles, the unfilled circle represents a repeat point (recycling) and open triangle the response to zero dose (recuperation). The sensitivitycorrected natural IRSL signal is interpolated onto the growth curve to give the equivalent dose, $\mathrm{D}_{\mathrm{e}}$ (in this case, $279 \mathrm{~Gy}$ ). The inset presents a typical natural IRSL decay curve measured at $290^{\circ} \mathrm{C}$. B) Dose recovery data from sample OSL78; filled circles represent $\mathrm{IR}_{50}$ data and unfilled circles the pIRIR 290 data. Note that the $\operatorname{pIRIR}_{290}$ data have been offset by $10 \mathrm{~Gy}$ on the given dose axis for presentation.

Fig. 6. Representative pictures of the Cap Blanc site. $\mathrm{U} 1=$ slightly stratified subtidal deposit. U2 = massive shallow water marine deposit. U3 = clast-supported and very poorly-sorted compact diamict comprising exclusively angular local basalts interpreted as cryopediment. U4 = stratified well-rounded and well-sorted medium to fine white littoral sand. U5 = cryopediment. Star corresponds to OSL sample locations. Numbered symbols (e.g. PS01) are particle size samples. A. Overall picture of the site. B. Close-up of U1. C. Close-up of the transition between U2 and U3. D. Close-up of the transition between U3 and U4. E. Close-up of U4 and the transition with U5. 
Fig. 7. Representative pictures of the Drift and Beach sites. Star corresponds to the position of the OSL sample. Numbered symbols (e.g. PS08) are particle size samples. A. The Drift site: homogeneous, moderately compact and massive red sand interpreted as glaciomarine deposit. B. The Beach site: slightly sub-horizontally stratified shallow water marine deposit.

Fig. 8. Representative pictures of the Camping site. Star corresponds to the position of the OSL sample. Numbered symbols (e.g. PS14) are particle size samples. A. Location of the site on the coastal cliff. The dashed line outlines the crested-shape of the deposit that lies directly on the sandstone bedrock. B. Alternating fine to medium sand with gravelly beds of sub-angular local basalt; the unit is interpreted as littoral deposit.

Fig. 9. RSL variation curves based on the different OSL and radiocarbon ages acquired in this study or in the available literature on different indicators throughout the Magdalen Islands. The grey plus symbols represent the terrestrial peat dated to $10.7 \mathrm{cal}$. $\mathrm{ka} \mathrm{BP}$ at modern level and to $10.8 \mathrm{cal}$. ka BP at $-2.2 \mathrm{~m}$ by Dredge et al. (1992). The cross indicates a radiocarbon age of $\sim 9.8 \mathrm{cal}$. ka BP acquired from a well-preserved piece of wood at a depth of $17 \mathrm{~m}$. The dashed lines and the question marks outline that the curve is suggested from current data. A. Post-LGM to the late Holocene period. B. Partial curve for the transition between late MIS 4 to MIS 3 by the addition of the Cap Blanc site (Entry Island) and the ACE site (Havre-Aubert Island).

Fig. 10. Glacio-isostatic depression curves for the southern (black circles), central (blue triangles) and northern archipelago (red circles). 
Table 1. Particle size data from this study.

\begin{tabular}{|c|c|c|c|c|c|c|c|c|c|c|}
\hline Site & Type of sediment & $\begin{array}{l}\text { Sample } \\
\text { no. }\end{array}$ & $\begin{array}{l}\text { Medium to coarse } \\
\text { sand (\%) }\end{array}$ & $\begin{array}{l}\text { Fine to very fine } \\
\text { sand (\%) }\end{array}$ & $\begin{array}{l}\text { Silt } \\
(\%)\end{array}$ & $\begin{array}{l}\text { Clay } \\
(\%)\end{array}$ & $\begin{array}{l}\text { Mean } \\
(\mu \mathrm{m})\end{array}$ & $\begin{array}{l}\text { Sorting } \\
(\phi)\end{array}$ & $\begin{array}{l}\text { Skewness } \\
(\phi)\end{array}$ & $\begin{array}{l}\text { Kurtosis } \\
(\phi)\end{array}$ \\
\hline Cap-Blanc & Marine (subtidal) & PS01 & 34 & 63 & 2 & 1 & 223.7 & 0.397 & 0.205 & 1.262 \\
\hline Cap-Blanc & Marine & PSO2 & 34 & 64 & 1 & 1 & 223.0 & 0.403 & 0.206 & 1.233 \\
\hline Cap-Blanc & Marine & PSO3 & 18 & 73 & 7 & 2 & 173.2 & 1.026 & 0.686 & 2.389 \\
\hline Cap-Blanc & Colluvial & PSO4 & 6 & 51 & 33 & 10 & 43.2 & 2.665 & 0.656 & 0.683 \\
\hline Cap-Blanc & Littoral (beach) & PS05 & 58 & 42 & 0 & 0 & 263.9 & 0.402 & -0.008 & 0.998 \\
\hline Cap-Blanc & Colluvial & PS06 & 1 & 67 & 25 & 7 & 48.0 & 2.360 & 0.750 & 0.903 \\
\hline Drift & Glaciomarine & PS07 & 0 & 80 & 16 & 4 & 88.3 & 1.490 & 0.659 & 2.544 \\
\hline Drift & Glaciomarine & PS08 & 0 & 69 & 29 & 2 & 62.5 & 1.524 & 0.567 & 1.562 \\
\hline Beach & Marine & PS09 & 1 & 91 & 6 & 2 & 129.8 & 0.723 & 0.257 & 1.380 \\
\hline Beach & Marine & PS10 & 1 & 90 & 7 & 2 & 130.2 & 0.745 & 0.224 & 1.185 \\
\hline Beach & Marine & PS11 & 0 & 75 & 22 & 3 & 76.2 & 1.419 & 0.578 & 2.349 \\
\hline Camping & Littoral (subtidal) & PS12 & 48 & 45 & 7 & 1 & 240.0 & 1.526 & 0.085 & 1.373 \\
\hline Camping & Littoral (subtidal) & PS13 & 25 & 59 & 14 & 1 & 140.5 & 1.405 & 0.282 & 1.459 \\
\hline Camping & Littoral (subtidal) & PS14 & 27 & 29 & 40 & 3 & 62.2 & 2.367 & 0.437 & 0.670 \\
\hline Hospital Pond & Marine & PS15 & 85 & 15 & 0 & 0 & 328.9 & 0.374 & 0.025 & 0.932 \\
\hline Hospital Pond & Marine & PS16 & 85 & 15 & 0 & 0 & 339.4 & 0.416 & 0.033 & 0.967 \\
\hline Hospital Pond & Marine & PS17 & 6 & 90 & 3 & 1 & 157.5 & 0.531 & 0.245 & 1.077 \\
\hline Hospital Pond & Marine & PS18 & 0 & 90 & 9 & 1 & 112.6 & 0.632 & 0.322 & 1.284 \\
\hline Hospital Pond & Marine & PS19 & 33 & 62 & 4 & 1 & 199.0 & 0.767 & 0.144 & 1.173 \\
\hline $\mathrm{BAH}$ & Marine & PS20 & 93 & 7 & 0 & 0 & 366.0 & 0.375 & -0.004 & 0.947 \\
\hline $\mathrm{BAH}$ & Marine & PS21 & 93 & 7 & 0 & 0 & 369.0 & 0.378 & -0.006 & 0.950 \\
\hline $\mathrm{BAH}$ & Marine & PS22 & 94 & 6 & 0 & 0 & 378.7 & 0.374 & 0.019 & 0.960 \\
\hline $\mathrm{BAH}$ & Marine & PS23 & 77 & 21 & 2 & 1 & 321.2 & 0.574 & 0.201 & 1.231 \\
\hline $\mathrm{BAH}$ & Marine & PS24 & 46 & 50 & 4 & 1 & 221.8 & 0.708 & 0.322 & 1.154 \\
\hline
\end{tabular}


Table 2. List of radiocarbon ages discussed in this paper.

\begin{tabular}{llllll}
\hline Site & Laboratory ID & Age ${ }^{14} \mathrm{C}$ a BP $\pm 1 \delta$ & Calibrated age $( \pm 2 \sigma)$ & Elevation (m) & Reference \\
\hline ACE & UCIAMS-74416 & $>46000$ & N/A & 15 & Rémillard et al. (2013) \\
ACE & UCIAMS-41189 & $47100 \pm 2700$ & N/A & 15 & Rémillard et al. (2013) \\
ACE & UCIAMS-74417 & $50100 \pm 3300$ & N/A & 15 & Rémillard et al. (2013) \\
ACE & UCIAMS-84792 & $47100 \pm 2300$ & N/A & 15 & Rémillard et al. (2013) \\
ACE & UCIAMS-84793 & $47800 \pm 2500$ & N/A & 15 & Rémillard et al. (2013) \\
AC-Lighthouse & UCIAMS-134737 & $8995 \pm 25$ & $10197 \pm 32$ & 13 & Rémillard et al. (2016) \\
Clermont & UCIAMS-134729 & $9430 \pm 25$ & $10656 \pm 73$ & 0 & Rémillard et al. (2016) \\
BAH & UCIAMS-134725 & $840 \pm 20$ & $418 \pm 84$ & -5 & This study \\
Hospital Pond & UCIAMS-134726 & $1125 \pm 20$ & $635 \pm 75$ & -5 & This study \\
Cap à Isaac & UCIAMS-39577 & $860 \pm 15$ & $761 \pm 28$ & -0.28 & Juneau (2012) \\
Cap à Isaac & UCIAMS-41190 & $1135 \pm 15$ & $1023 \pm 44$ & -0.82 & Juneau (2012) \\
Cap de l'Église & UCIAMS-39582 & $930 \pm 15$ & $853 \pm 58$ & -0.13 & Juneau (2012) \\
Cap de l'Église & UCIAMS-39585 & $460 \pm 15$ & $512 \pm 13$ & 0.55 & Juneau (2012) \\
Cap de l'Église & UCIAMS-52766 & $350 \pm 15$ & $400 \pm 82$ & 0.75 & Juneau (2012) \\
Anse aux renards & UCIAMS-39580 & $625 \pm 15$ & $606 \pm 50$ & -0.14 & Juneau (2012) \\
Anse aux renards & UCIAMS-41191 & $585 \pm 15$ & $634 \pm 49$ & 0.35 & Juneau (2012) \\
Anse aux renards & UCIAMS-41192 & $145 \pm 20$ & $143 \pm 138$ & 0.35 & Juneau (2012) \\
Anse aux renards & UCIAMS-45696 & $110 \pm 20$ & $144 \pm 122$ & -0.18 & Juneau (2012) \\
Grand Barachois & UL-3272 & $1140 \pm 60$ & $1080 \pm 148$ & 0.56 & Juneau (2012) \\
Petite Échouerie & UCIAMS-39583 & $930 \pm 20$ & $854 \pm 61$ & -0.16 & Juneau (2012) \\
Baie du Bassin & UCIAMS-39578 & $625 \pm 15$ & $606 \pm 50$ & -3.1 & Juneau (2012) \\
Baie du Bassin & UCIAMS-41188 & $1885 \pm 15$ & $1811 \pm 70$ & 0.31 & Juneau (2012) \\
Baie du Bassin & UCIAMS-39575 & $120 \pm 15$ & $144 \pm 123$ & Juneau (2012) \\
\hline
\end{tabular}


Table 3. Radionuclide concentrations, water content and total dose rates of all the samples. Nat $=$ observed water content; Sat = laboratory measured saturation water content. Derivation of life time average water content is discussed in the Radionuclide analysis and dosimetry section.

\begin{tabular}{|c|c|c|c|c|c|c|c|c|c|c|c|}
\hline \multirow[b]{2}{*}{ Site } & \multirow[b]{2}{*}{$\begin{array}{l}\text { Sample } \\
\text { ID }\end{array}$} & \multicolumn{4}{|c|}{ Radionuclide activities (Bq/kg) } & \multicolumn{2}{|c|}{ Dry dose rate (Gy/ka) } & \multicolumn{3}{|c|}{ Water content meas. (\%) } & \multirow[b]{2}{*}{$\begin{array}{l}\text { Total dose rate } \\
\text { (Gy/ka) }\end{array}$} \\
\hline & & ${ }^{238} \mathrm{U}$ & ${ }^{226} \mathrm{Ra}$ & ${ }^{232} \mathrm{Th}$ & ${ }^{40} \mathrm{~K}$ & Gamma & Beta & Nat & Sat & $\begin{array}{l}\text { Life time } \\
\text { average }\end{array}$ & \\
\hline Camping & OSL51 & $12 \pm 5$ & $10.7 \pm 0.4$ & $11.7 \pm 0.4$ & $455 \pm 10$ & $0.571 \pm 0.012$ & $1.25 \pm 0.03$ & 11 & 38 & 19 & $1.63 \pm 0.09$ \\
\hline Entry - Cap Blanc & OSL53 & $7 \pm 4$ & $6.4 \pm 0.3$ & $6.4 \pm 0.3$ & $399 \pm 8$ & $0.434 \pm 0.009$ & $1.04 \pm 0.02$ & 5 & 30 & 15 & $1.30 \pm 0.08$ \\
\hline Entry - Cap Blanc & OSL54 & $27 \pm 4$ & $10.0 \pm 0.3$ & $12.6 \pm 0.3$ & $483 \pm 9$ & $0.602 \pm 0.011$ & $1.37 \pm 0.03$ & 4 & 51 & 25 & $1.58 \pm 0.08$ \\
\hline Entry - Cap Blanc & OSL55 & $8 \pm 3$ & $5.2 \pm 0.3$ & $5.3 \pm 0.3$ & $383 \pm 9$ & $0.401 \pm 0.009$ & $0.99 \pm 0.03$ & 4 & 40 & 20 & $1.23 \pm 0.07$ \\
\hline Entry - Cap Blanc & OSL56 & $21 \pm 3$ & $9.1 \pm 0.3$ & $4.0 \pm 0.2$ & $378 \pm 7$ & $0.411 \pm 0.010$ & $1.05 \pm 0.02$ & 4 & 42 & 21 & $1.30 \pm 0.07$ \\
\hline Entry - Cap Blanc & OSL57 & $11 \pm 5$ & $12.7 \pm 0.4$ & $10.2 \pm 0.4$ & $568 \pm 13$ & $0.66 \pm 0.02$ & $1.51 \pm 0.04$ & 7 & 33 & 16 & $1.94 \pm 0.11$ \\
\hline Entry - Drift & OSL58 & $9 \pm 5$ & $12.4 \pm 0.4$ & $13.4 \pm 0.5$ & $457 \pm 11$ & $0.604 \pm 0.014$ & $1.26 \pm 0.03$ & 6 & 39 & 19 & $1.65 \pm 0.09$ \\
\hline Entry - Beach & OSL59 & $28 \pm 5$ & $19.6 \pm 0.5$ & $18.5 \pm 0.4$ & $524 \pm 10$ & $0.77 \pm 0.02$ & $1.56 \pm 0.03$ & 19 & 40 & 20 & $1.98 \pm 0.11$ \\
\hline Bassin & OSL101 & $26 \pm 7$ & $20.8 \pm 0.6$ & $19.4 \pm 0.7$ & $510 \pm 13$ & $0.77 \pm 0.02$ & $1.51 \pm 0.04$ & 28 & 25 & 13 & $2.08 \pm 0.13$ \\
\hline
\end{tabular}


Table 4. Sample location, elevation, depth, equivalent doses $\left(D_{e}\right)$ and resulting quartz OSL ages. The equivalent dose tabulated is the average of ' $n$ ' estimates (202 accepted estimates out of 203 measured aliquots).

\begin{tabular}{|c|c|c|c|c|c|c|c|c|c|}
\hline Site & Sample ID & Environment & Lat. $(\mathrm{N})$ & Long. (W) & Elev. (m) & Depth $(\mathrm{cm})$ & $\mathrm{D}_{\mathrm{e}}$ (Gy) & $n$ & Age $\pm 1 \sigma(\mathrm{ka})$ \\
\hline Camping & OSL51 & Littoral (subtidal) & 47.346252 & 61.879590 & 16 & 150 & $156 \pm 7$ & 19 & $96 \pm 7$ \\
\hline Entry - Cap Blanc & OSL53 & Shallow marine & 47.269535 & 61.698221 & 30 & 900 & $72 \pm 4$ & 15 & $55 \pm 5$ \\
\hline Entry - Cap Blanc & OSL54 & Shallow marine & 47.269535 & 61.698221 & 32 & 700 & $94 \pm 3$ & 30 & $60 \pm 4$ \\
\hline Entry - Cap Blanc & OSL55 & Beach & 47.269535 & 61.698221 & 34.5 & 450 & $63 \pm 3$ & 15 & $51 \pm 4$ \\
\hline Entry - Cap Blanc & OSL56 & Beach & 47.269535 & 61.698221 & 37 & 200 & $80 \pm 3$ & 29 & $61 \pm 4$ \\
\hline Entry - Cap Blanc & OSL57 & Colluvial & 47.269535 & 61.698221 & 37.5 & 150 & $115 \pm 5$ & 30 & $60 \pm 5$ \\
\hline Entry - Drift & OSL58 & Shallow marine & 47.269441 & 61.696845 & 40 & 150 & $41 \pm 2$ & 20 & $25 \pm 2$ \\
\hline Entry - Beach & OSL59 & Shallow marine & 47.268591 & 61.710130 & 2.6 & 650 & $31.3 \pm 1.1$ & 22 & $15.8 \pm 1.1$ \\
\hline Bassin & OSL101 & Lagoonal & 47.235024 & 61.898210 & 0 & 350 & $164 \pm 11$ & 22 & $79 \pm 7$ \\
\hline
\end{tabular}


Table 5. Sample equivalent doses $\left(D_{e}\right)$ and resulting IRSL ages. The equivalent dose tabulated is the average of ' $n$ ' estimates.

\begin{tabular}{lllllll}
\hline Site & Sample ID & $n$ & $\begin{array}{l}\mathrm{D}_{e} \\
\mathrm{I}_{50}(\mathrm{~Gy})\end{array}$ & $\begin{array}{l}\mathrm{D}_{\mathrm{e}} \\
\mathrm{pIRIR}_{290}(\mathrm{~Gy})\end{array}$ & $\begin{array}{l}\text { Age } \pm 1 \sigma \\
\mathrm{IR}_{50}(\mathrm{ka})\end{array}$ & $\begin{array}{l}\text { Age } \pm 1 \sigma \\
\text { pIRIR } 290\end{array}$ \\
\hline Camping & OSL51 & 12 & $221 \pm 26$ & $286 \pm 14$ & $89 \pm 11$ & $115 \pm 8$ \\
Bassin & OSL101 & 12 & $188 \pm 17$ & $269 \pm 20$ & $64 \pm 7$ & $92 \pm 8$ \\
\hline
\end{tabular}


Table 6. List of the indicators dated with OSL used for the RSL curve reconstruction. Site and island on which it is exposed, sample ID, type of indicator, location, elevation and age of each indicator. The related global sea-level is estimated from the study of Stanford et al. (2011) for the LGM and post-LGM points, and from Caputo (2007) for the MIS 4/MIS 3 ages. The minimum crustal depression is derived from the age and the related global sea-level estimated.

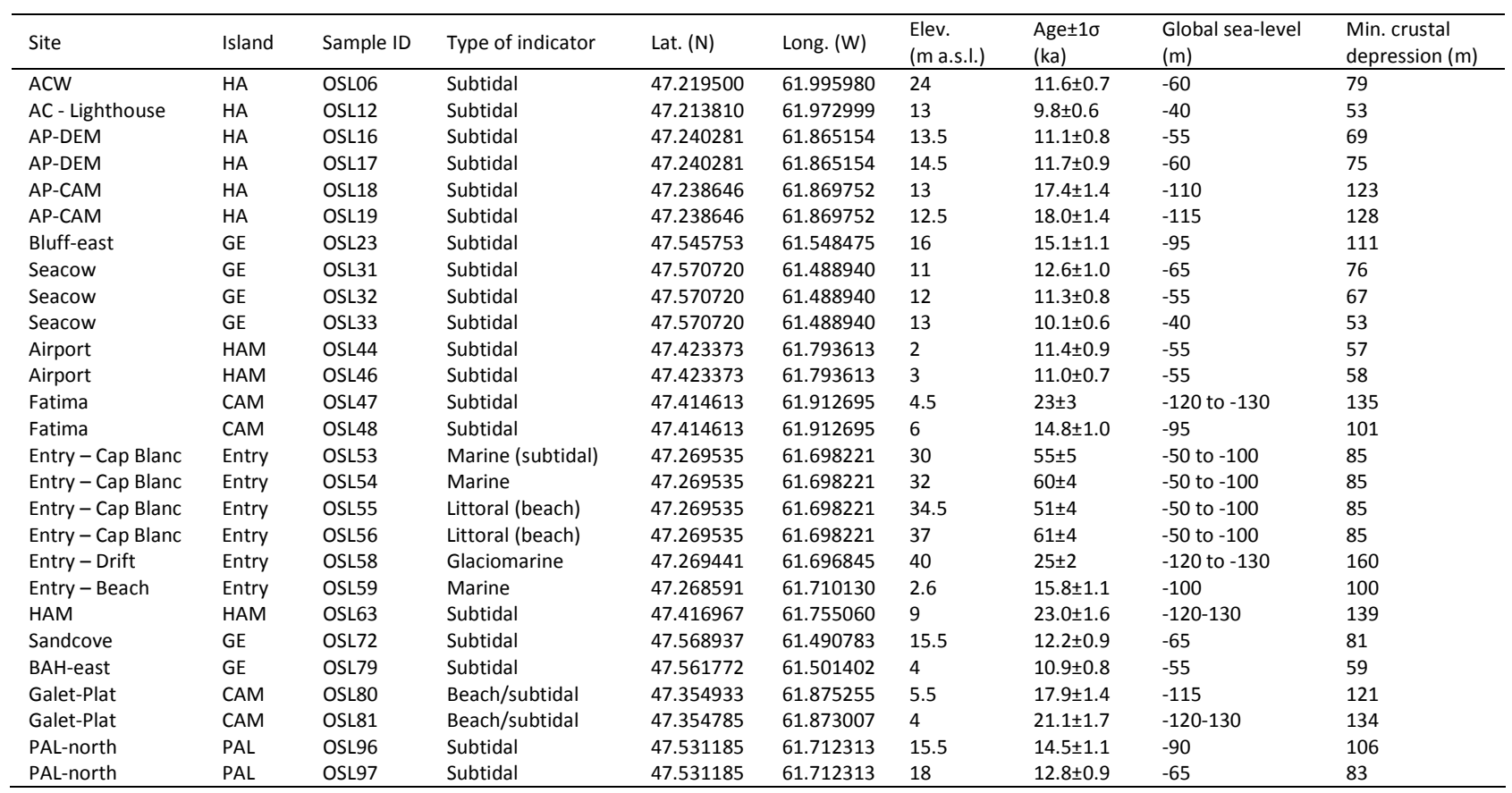


Time (cal. BP)

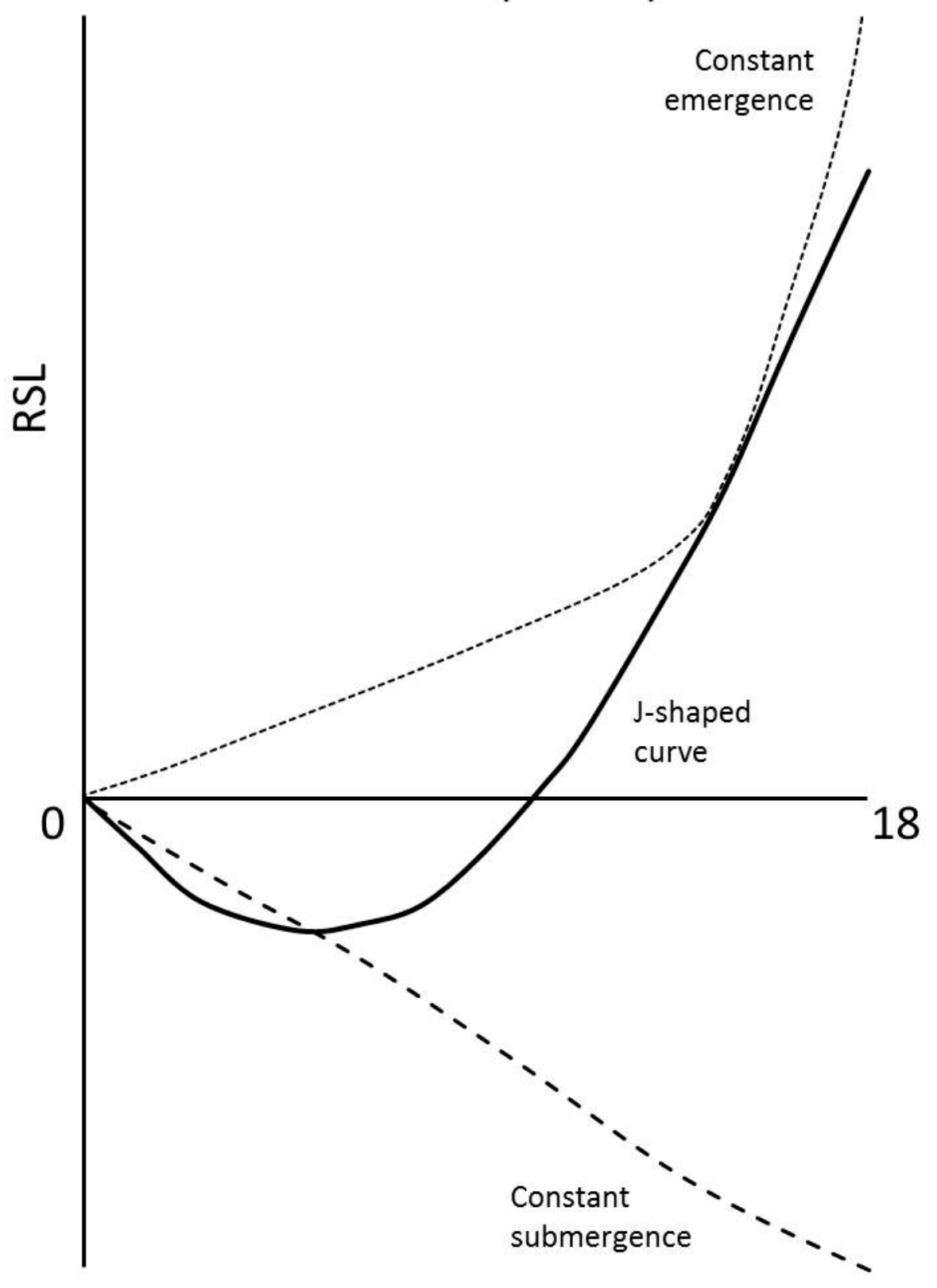

Fig. 1 


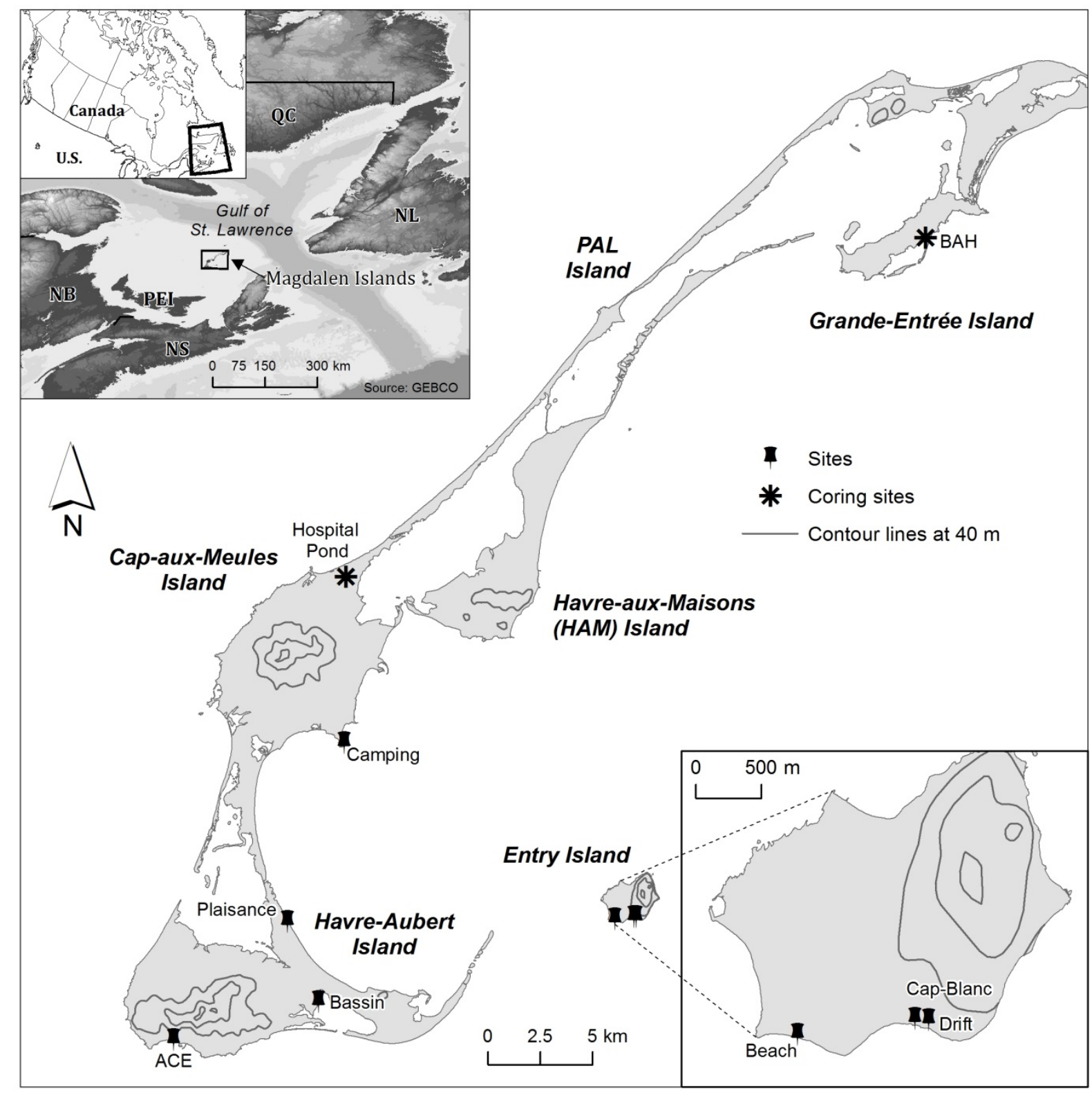

Fig. 2 

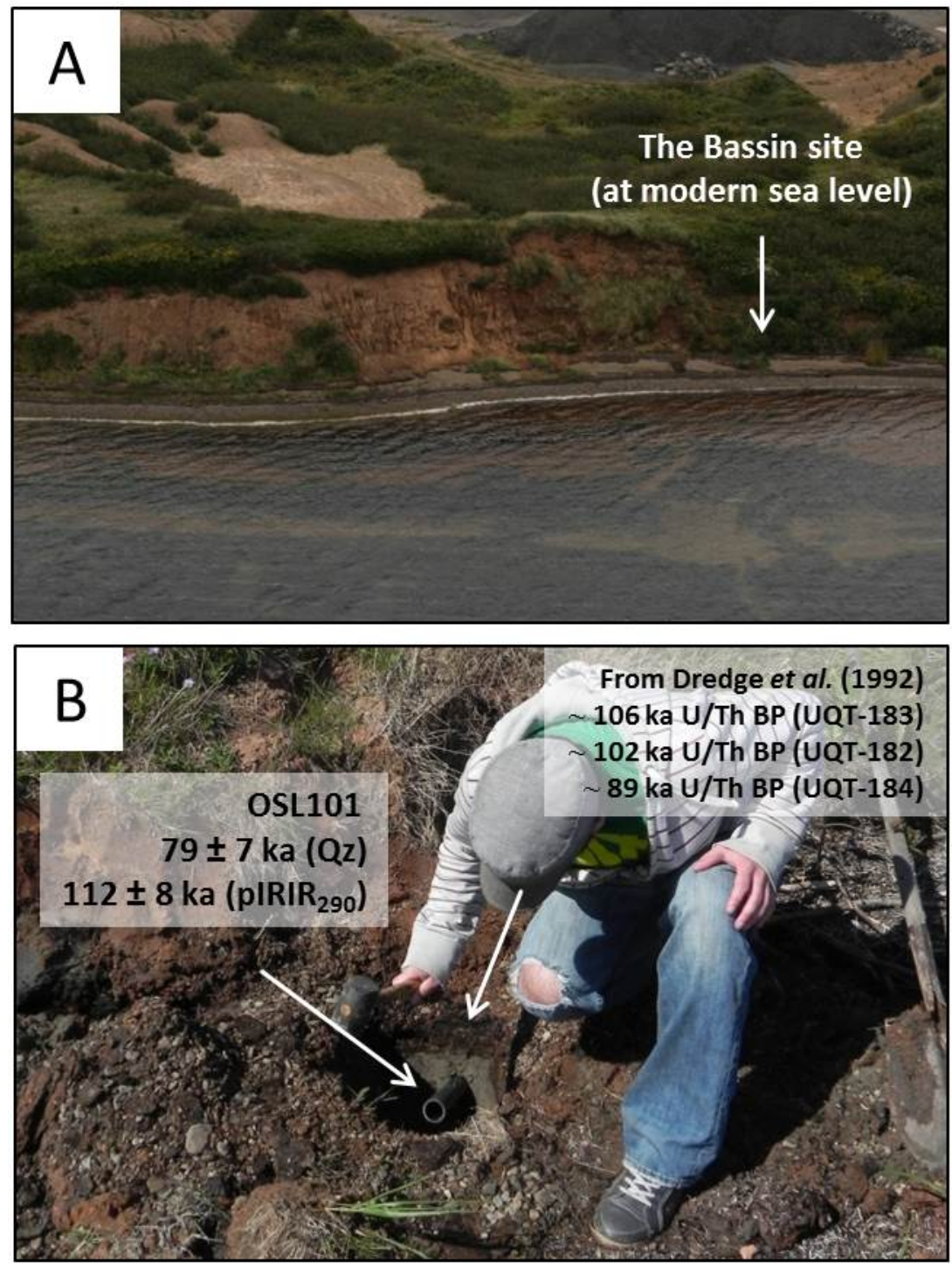

Fig. 3 

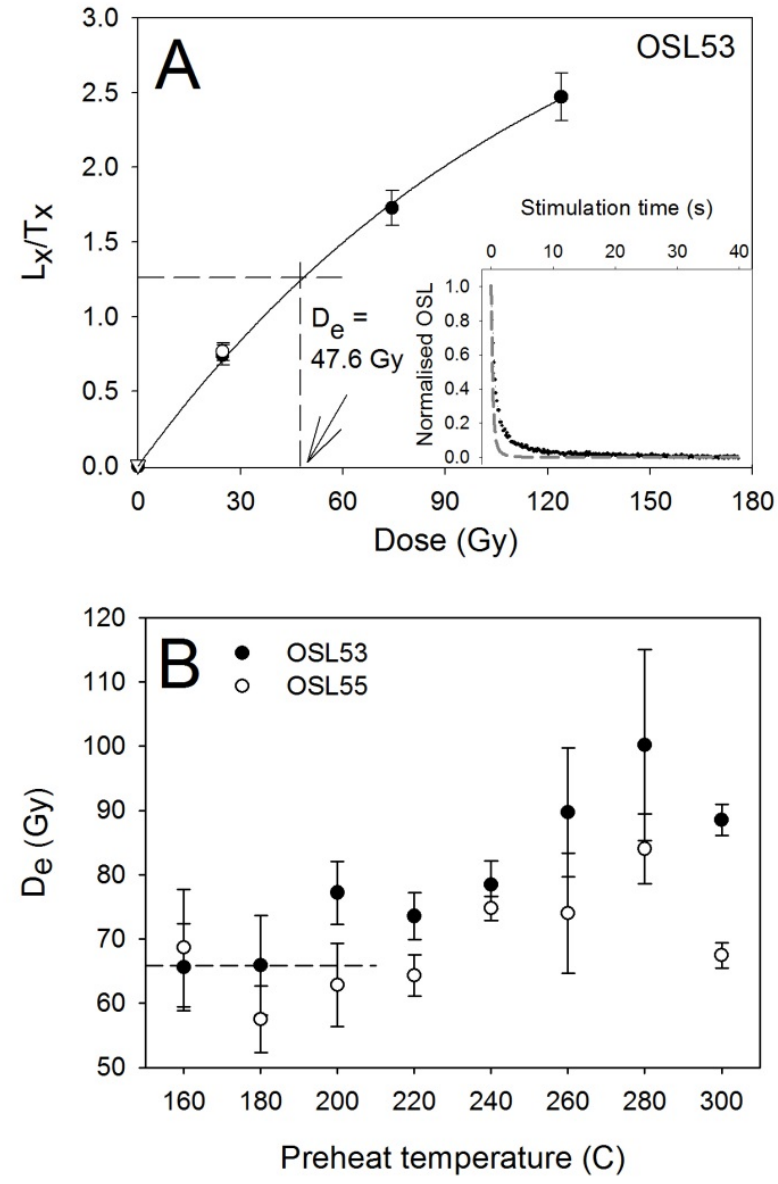

Fig. 4

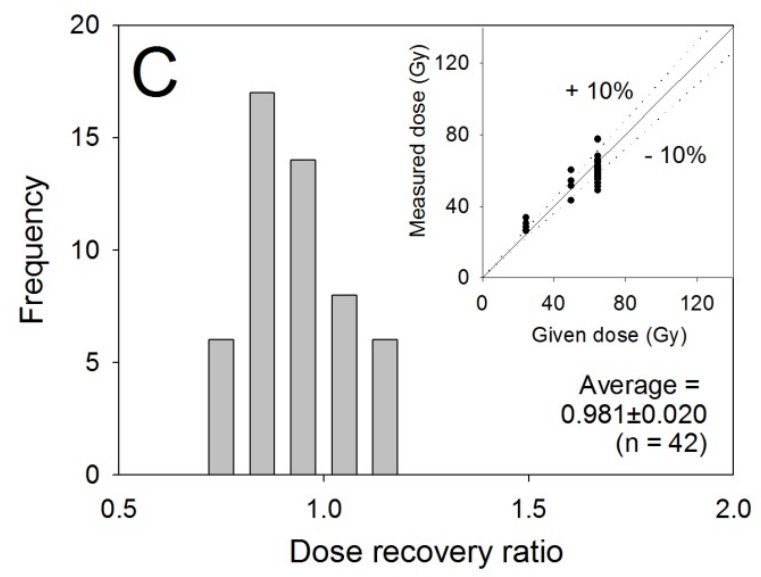



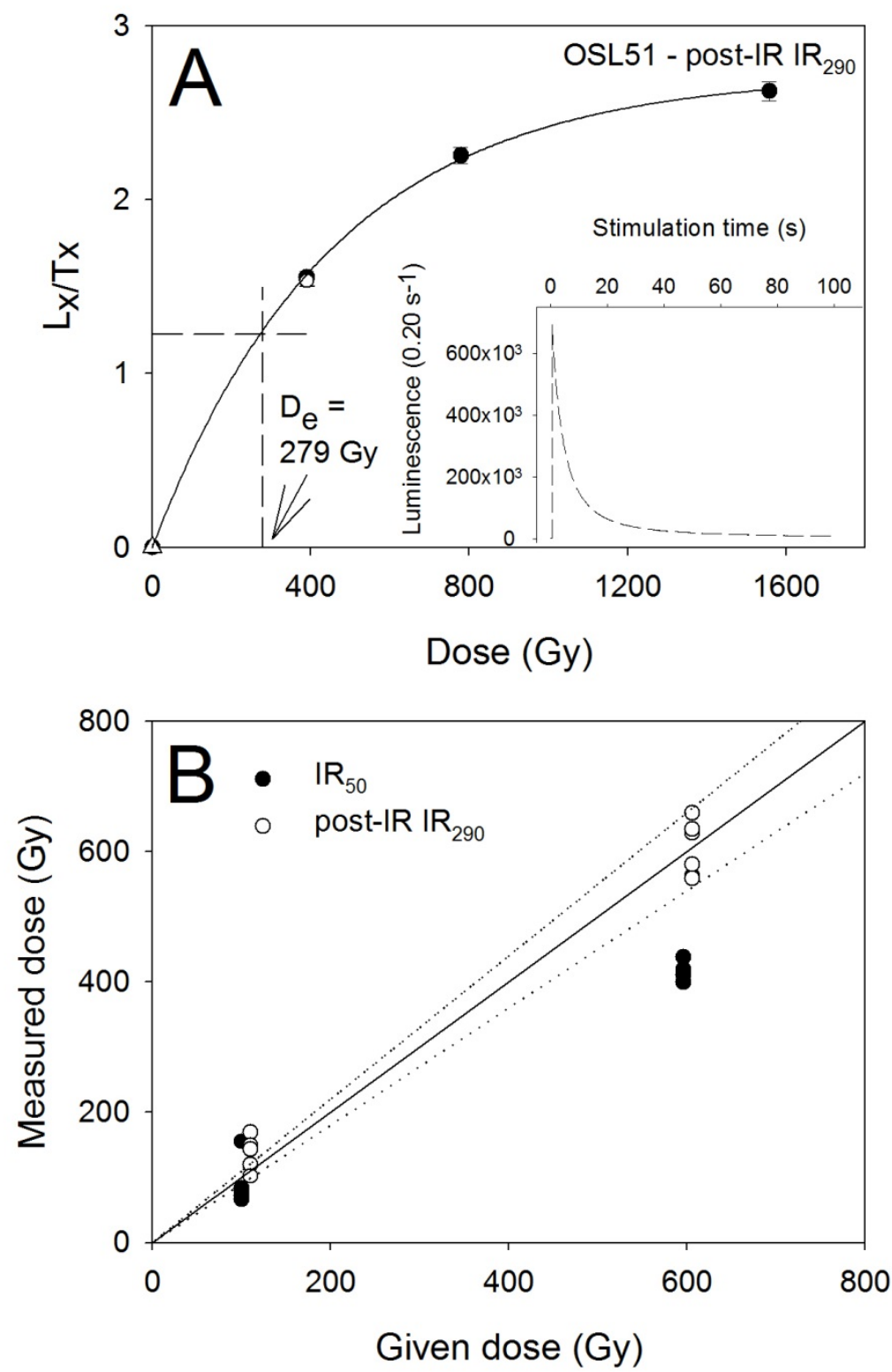

Fig. 5 


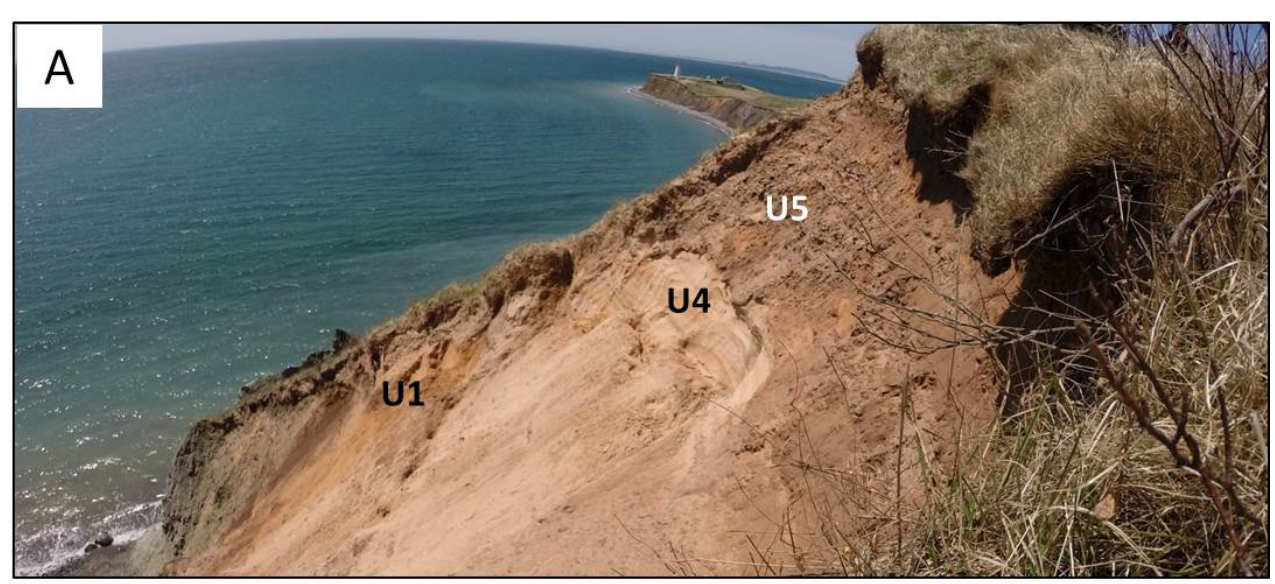

Fig. 6
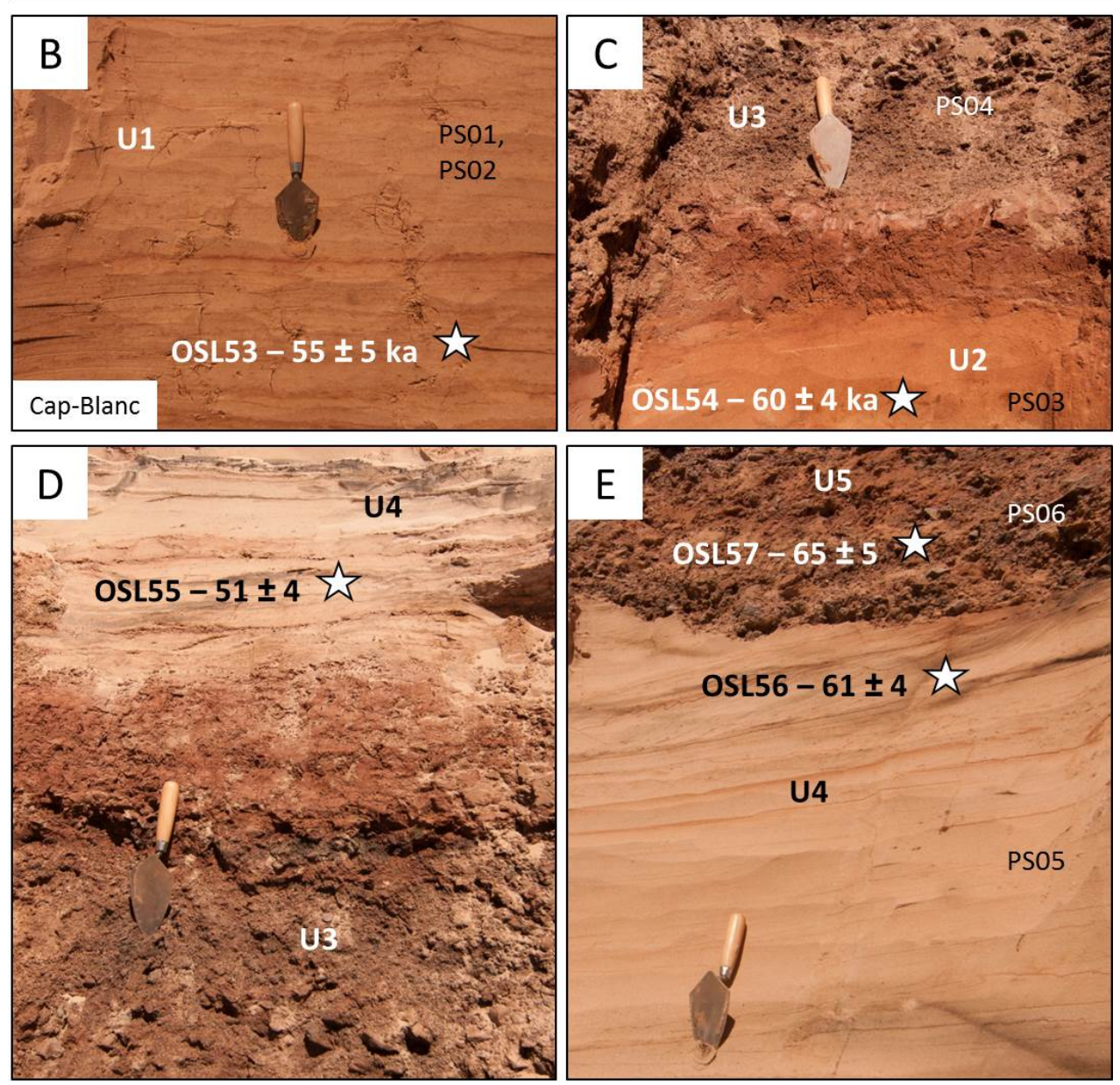


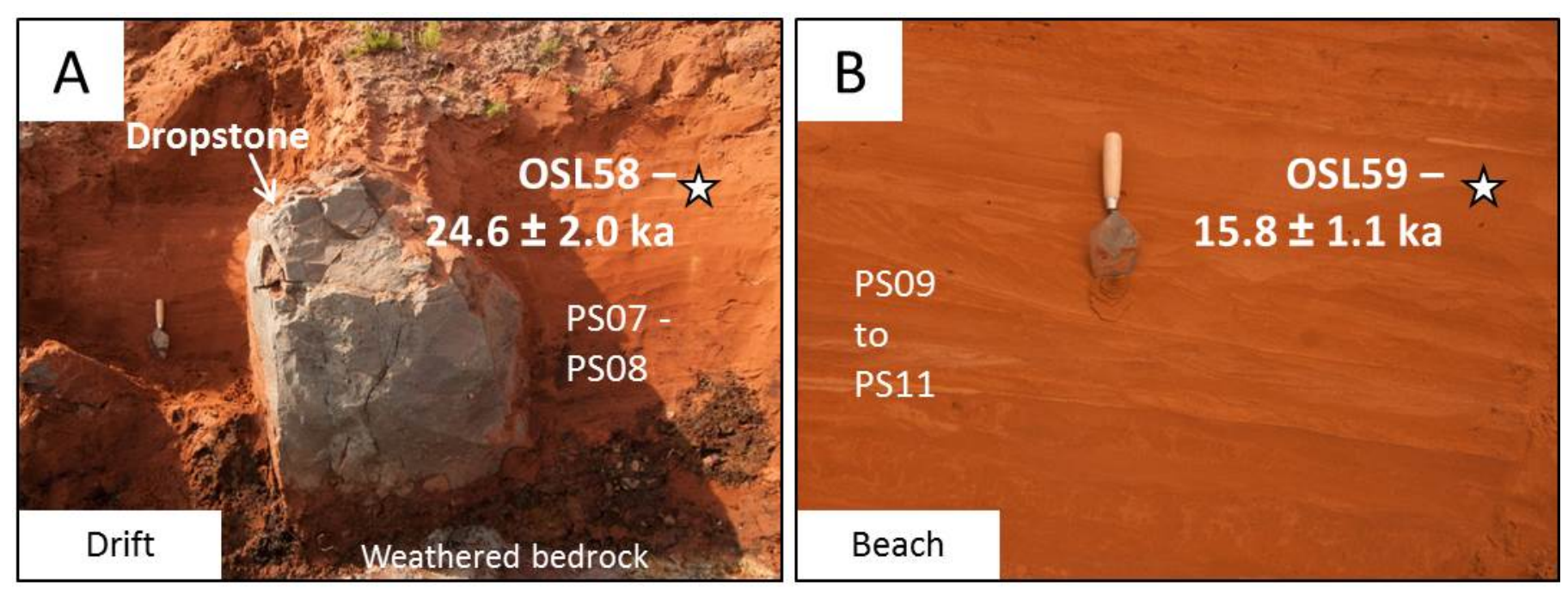

Fig. 7 


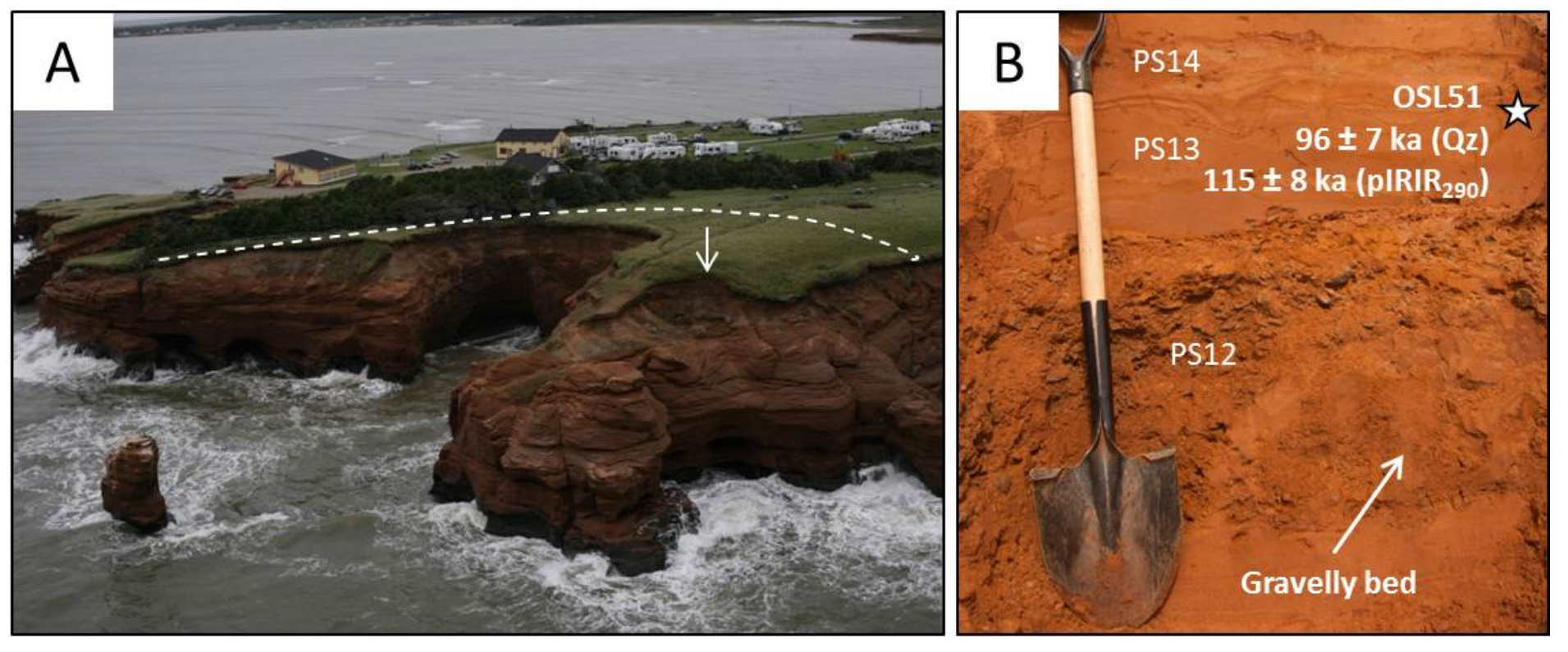

Fig. 8 


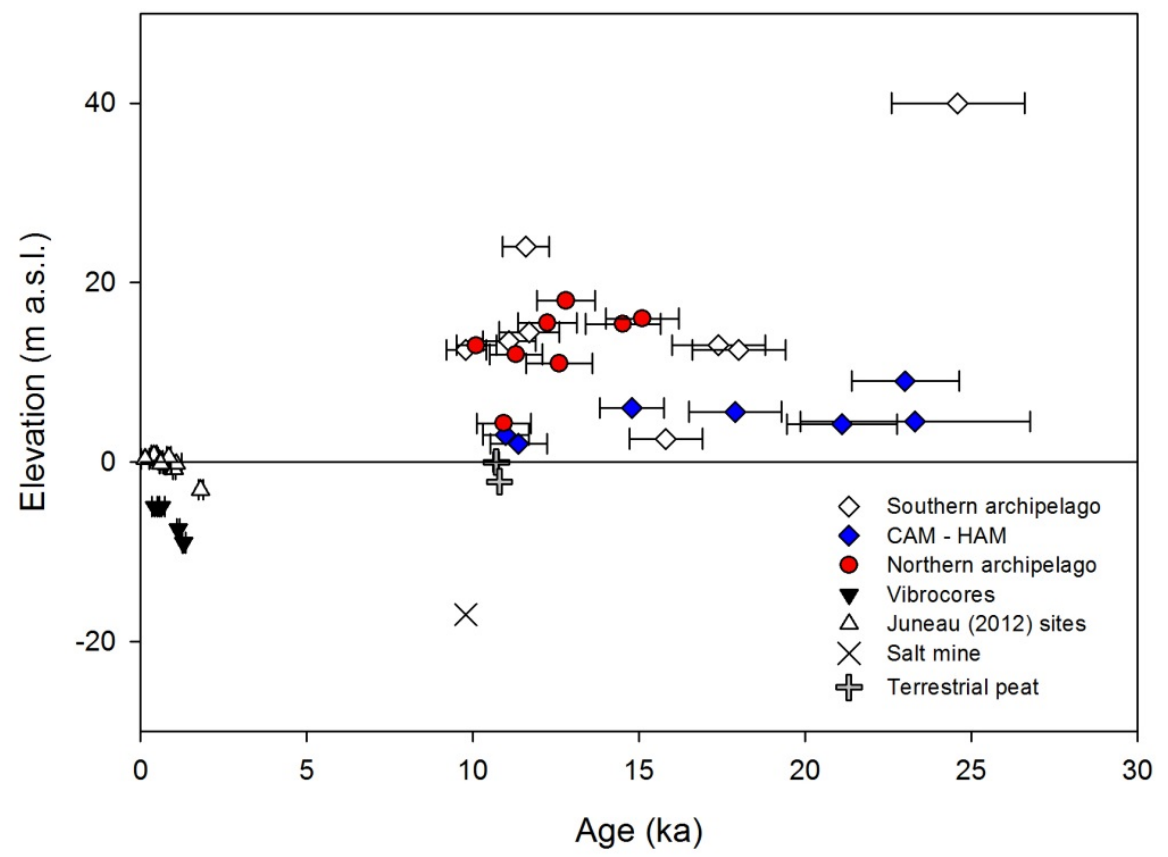

Fig. 9

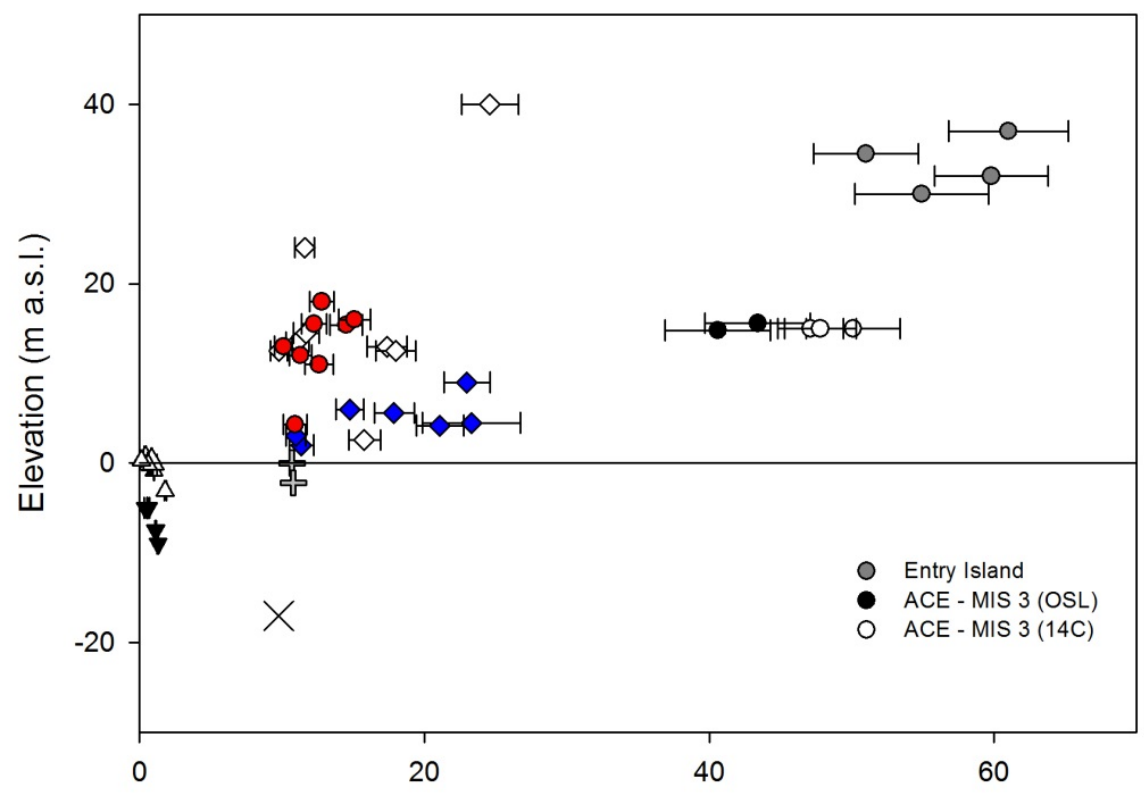

Age (ka) 


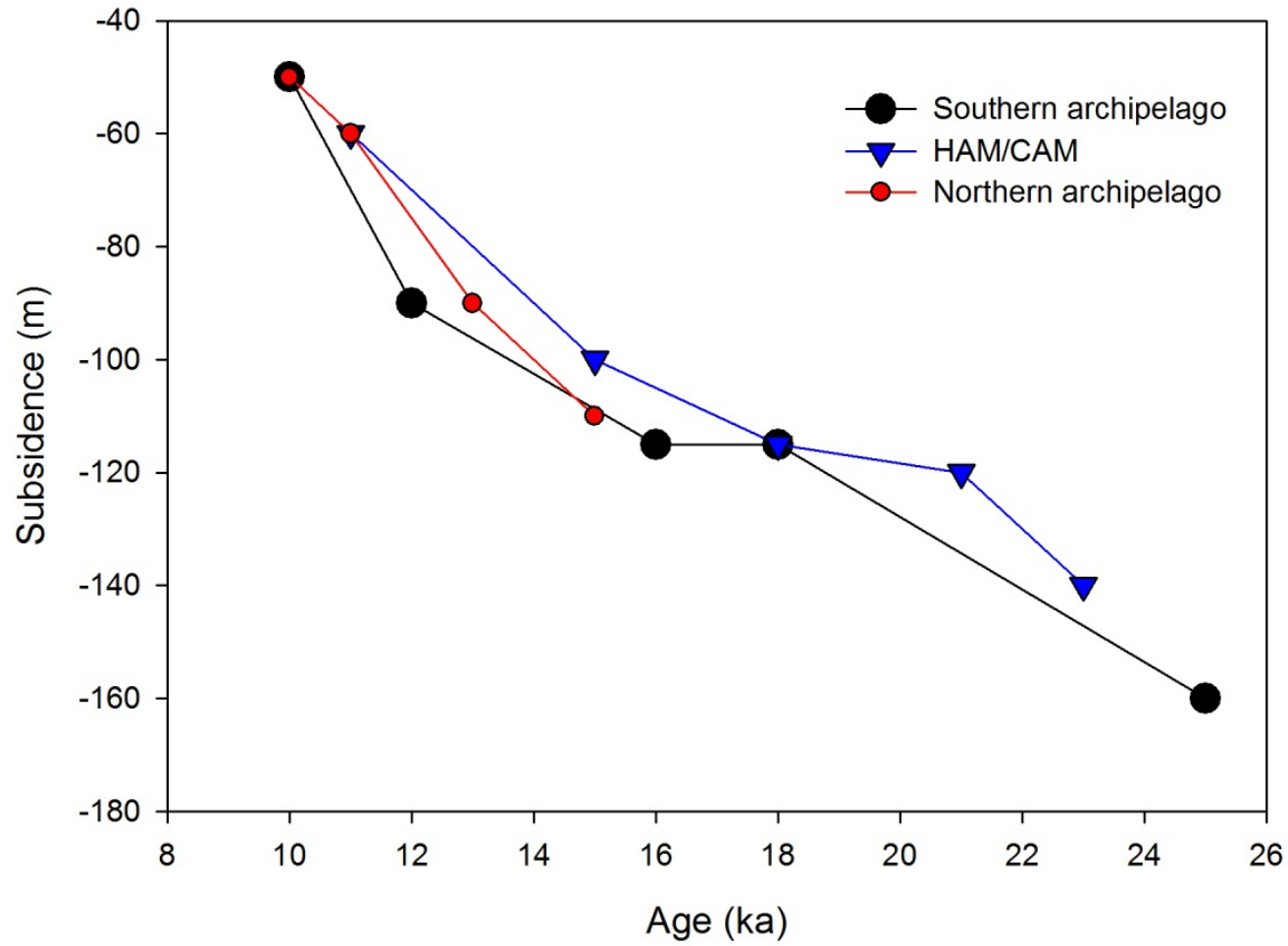

Fig. 10 